\title{
Working
}

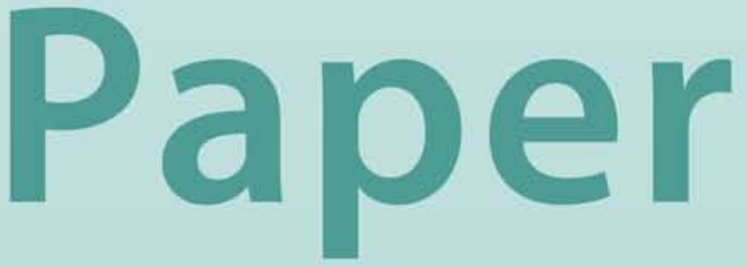


Foreign Aid and Real Exchange Rate Adjustments in a Financially Constrained Dependent Economy

\author{
Valerie Cerra, Serpil Tekin, and \\ Stephen J. Turnovsky
}




\title{
IMF Working Paper
}

\author{
IMF Institute
}

\section{Foreign Aid and Real Exchange Rate Adjustments in a Financially Constrained Dependent Economy*}

\section{Prepared by Valerie Cerra, Serpil Tekin, and Stephen J. Turnovsky ${ }^{\dagger}$}

\author{
Authorized for distribution by Andrew Feltenstein
}

August 2008

\begin{abstract}

\section{This Working Paper should not be reported as representing the views of the IMF.} The views expressed in this Working Paper are those of the author(s) and do not necessarily represent those of the IMF or IMF policy. Working Papers describe research in progress by the author(s) and are published to elicit comments and to further debate.

A dynamic dependent-economy model is developed to investigate the role of the real exchange rate in determining the effects of foreign aid. If capital is perfectly mobile between sectors, untied aid has no longrun impact on the real exchange rate. A decline in the traded sector occurs because aid, being denominated in traded output, substitutes for exports in financing imports. While untied aid causes short-run real exchange appreciation, this response is very temporary and negligibly small. Tied aid, by influencing sectoral productivity, does generate permanent relative price effects. The analysis, which employs extensive numerical simulations, emphasizes the tradeoffs between real exchange adjustments, long-run capital accumulation, and economic welfare, associated with alternative forms of foreign aid.
\end{abstract}

JEL Classification Numbers: F35; F31; F41; E62

Keywords: Foreign aid; real exchange rate; fiscal policy; debt; capital accumulation; welfare analysis

Authors’ E-Mail Addresses: vcerra@imf.org; tekins@u.washington.edu; sturn@u.washington.edu

\footnotetext{
* This paper has benefited from presentations at the University of Washington and the IMF. The constructive comments of Aleš Buliŕr, Yu-chin Chen, and Leslie Lipschitz are gratefully acknowledged. Work on this project began when Turnovsky visited the IMF Institute in April 2006. He gratefully acknowledges the hospitality extended during that visit. This research is adapted from Chapter 1 of Tekin's Ph.D. thesis written at the University of Washington under Turnovsky's supervision. Substantial financial support for for this project has been provided by the Castor Endowment at the University of Washington

${ }^{\dagger}$.Valerie Cerra, IMF; Serpil Tekin, University of Washington; Stephen J. Turnovsky, University of Washington.
} 


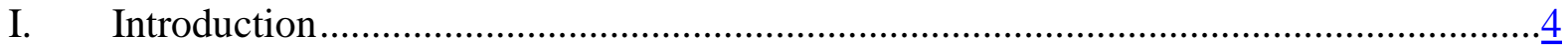

II. Two Sector Model of Foreign Aid ........................................................................

A. The Economic Structure........................................................................

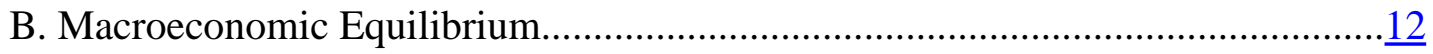

III. Steady State Equilibrium ................................................................................ 14

A. Long-Run Effects of Transfers on the Relative Price ........................................

B. Transfers, Economic Activity, and the Dutch Disease......................................

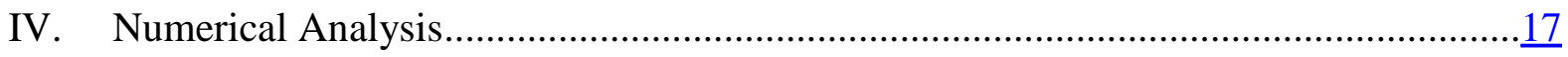

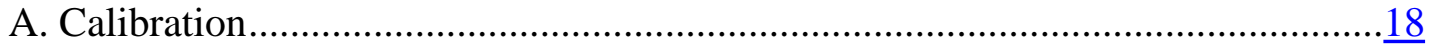

B. Optimal Government Spending................................................................

C. Initial Benchmark Equilibria .....................................................................

V. Foreign Aid Flows: General Characteristics of Real Exchange Rates ........................20

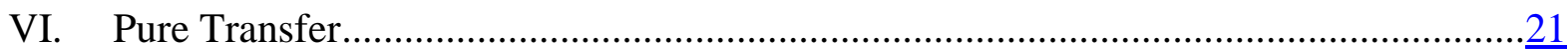

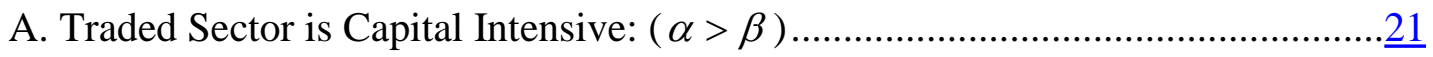

B. Nontraded sector is capital intensive: $(\beta>\alpha)$................................................22

VII. Productive Government Spending in the Traded Sector ............................................22

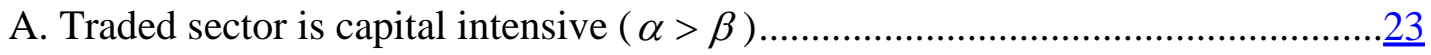

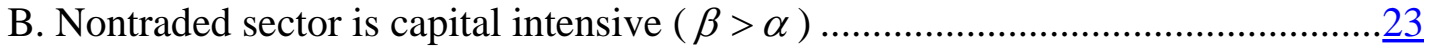

VIII. Productive Government Spending in the Nontraded Sector .....................................24

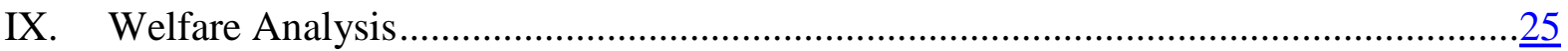

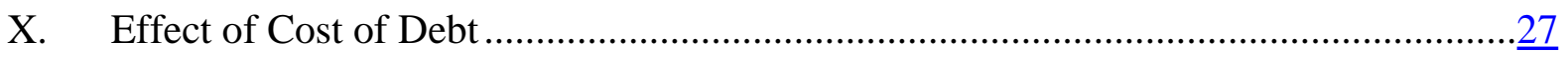

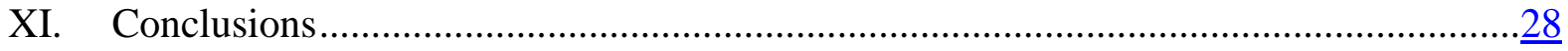

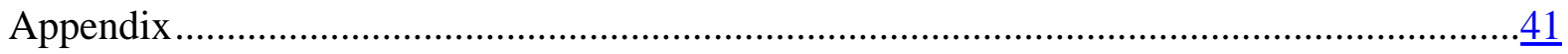

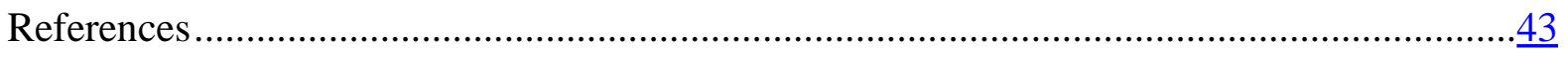

Tables

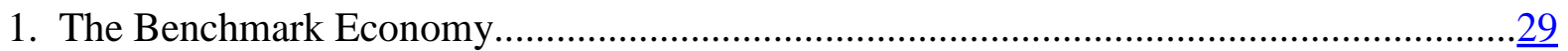

2. Key Steady-State Equilibrium Ratios ........................................................................29

3. Steady-State Responses to Permanent Changes .........................................................

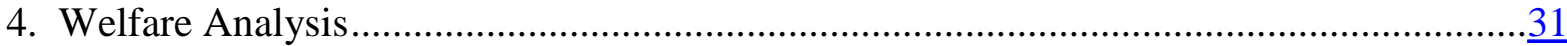


Figures

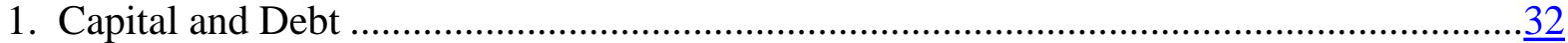

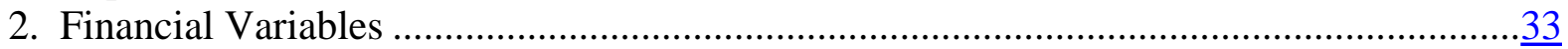

3. Sectoral Activity and Output ...........................................................................................

4. Consumption and Welfare ..........................................................................................

5. Sensitivity to Borrowing Premium: Untied Transfer......................................................

6. Sensitivity to Borrowing Premium: Productive Transfer to Traded Sector..........................39

7. Sensitivity to Borrowing Premium: Productive Transfer to Nontraded Sector ....................40 


\section{INTRODUCTION}

Foreign aid is an important channel whereby wealth is transferred from richer to poorer nations. Both the magnitude and the scope of these international transfers increased dramatically during the latter part of the 20th century, to the point where by the end of the millennium official development assistance from members of the OECD and OPEC countries had reached nearly $\$ 60$ billion. $^{1}$ Moreover, in July 2005, finance ministers of the G-8 countries pledged $\$ 50$ billion in additional aid to low income countries by 2010, as part of an effort to help poor economies achieve the Millennium development goals by 2015.

How foreign aid is allocated in a resource-scarce economy is important for both donors and recipients. This has generated an extensive debate as to whether international transfers should be "untied" ("pure”) or "tied” ("productive”). Aid, granted in the form of pure transfers, reflects the desires of donor countries to provide income support to reduce poverty and raise consumption levels. But a second key motivation for aid is to facilitate economic development and growth by directly investing in the productive capacity of the private sector.

World Bank studies suggest that over time a larger share of foreign aid has become "tied" in the sense of being linked to investments in public investment projects (see footnote 1). This change has been dictated mainly by the growing infrastructure needs of developing countries. But financing the required investment in infrastructure has proven to be a challenging task for these economies. Most such countries have significantly restricted public sector borrowing after the debt-crisis of the early 1980s, while at the same time their infrastructure requirements have increased steadily. ${ }^{2}$ Facing such fiscal constraints, governments in developing countries have turned to external financing, in the form of tied foreign aid, as a significant source of financing public investment.

The question of what form foreign aid should take has led to a large, but inconclusive, empirical literature on the link between foreign aid, economic growth, and development; see Hansen and Tarp (2001), Burnside and Dollar (2000), Collier and Dollar (2002), Easterly (2003), Easterly, Levine and Roodman (2004), and Dalgaard, Hansen, and Tarp (2004). Most of the empirical studies lack firm theoretical underpinnings, causing Hansen and Tarp (2001) to call for more theoretical work. Recently, Chatterjee, Sakoulis, and Turnovsky (2003) and Chatterjee and Turnovsky (2007) have developed a one-sector general equilibrium-growth framework, thereby providing a more formal analytical framework within which the growthaid relationship can be studied. Their main message is that the relative merits of tied versus untied aid programs on economic growth and welfare depend crucially upon a number of key structural characteristics of the recipient economy. ${ }^{3}$

\footnotetext{
${ }^{1}$ World Bank (1994, 2004).

${ }^{2}$ A 1994 World Bank study has estimated these requirements to be $\$ 200$ billion a year.

${ }^{3}$ These include: (i) costs of installing the publicly provided capital, (ii) substitutability between public and private capital in production, (iii) access to the world financial market, (iv) opportunities for domestic cofinancing of infrastructure projects (v) flexibility of labor supply; see Chatterjee and Turnovsky (2007). Adam
}

(continued...) 
One aspect that has received little attention is the behavior of relative prices. At issue here is whether the inflows of foreign aid cause a real exchange rate appreciation, leading to an adverse impact on the country's competitiveness. This could occur through two channels. First, untied aid may generate conventional Dutch disease effects. ${ }^{4}$ That is, by increasing the supply of tradable goods and lowering their relative price, resources are shifted to the nontraded sector, thereby reducing the size of the country's export sector and thus adversely affecting its growth rate. Second, to the extent that the aid is tied directly to production, and thus alters the relative productivity of the traded versus the nontraded sector, it will further influence relative prices, and therefore resource allocation, through the Balassa-Samuelson effect. $^{5}$

Empirical research demonstrates a mixed relationship between Dutch disease symptoms and aid. For example, Kang, Prati, and Rebucci (2007) find that aid has a detrimental impact on growth and exports in half of their sample of 38 countries with negative effects strongly associated with exchange rate over-valuation. However, they find that aid improves growth and exports in the other half of the sample, suggesting that not all countries are plagued with the Dutch disease. Nkusu (2004) argues that the Dutch disease need not occur in low-income countries that can draw upon their idle productive capacity to satisfy the aid-induced increased demand. In contrast, Rajan and Subramanian (2005) do find evidence of the Dutch disease leading to adverse effects on growth, even for economies adopting "good policies" in the Burnside-Dollar sense.

Clearly, the effects of foreign aid on competitiveness, and consequently on overall economic performance, remain a concern for policy makers and thus require careful analysis. ${ }^{6}$ The objective of this paper is to provide such an analysis, by employing a dynamic two-sector dependent economy model, and analyzing the fiscal options for absorbing the developmental assistance. In addition to considering the choice between tied and untied aid, we also compare the effects of allocating tied aid between the productivity-enhancement of the traded sector and that of the nontraded sector.

In analyzing the model, we pay particular attention to the adjustments of relative price in the transmission of foreign aid. While in the short run pure foreign aid is associated with

and Bevan (2006) employ a simple static model and draw a similar conclusion that with sectoral spillovers, the relationship between aid, growth, and output is not necessarily straightforward. Dalgaard (2008) analyzes the effectiveness of foreign aid under different donor policy rules in a one-sector overlapping generations model, in many ways paralleling the work of Chatterjee and Turnovsky.

\footnotetext{
${ }^{4}$ The original analysis of the Dutch disease by Corden and Neary (1982) and Corden (1984) employed a static framework. Early dynamic studies based on intertemporal optimization include Brock (1988) and van Wincoop (1993).

${ }^{5}$ See Balassa (1964) and Samuelson (1964). The Balassa-Samuelson effect refers to the enhanced productivity of the traded sector causing an appreciation of the real exchange rate.

${ }^{6}$ Issues concerning the volatility of aid flows are also important, but are not addressed here; see e.g. Isard, Lipschitz, Mourmouras, and Yontcheva (2006), Arellano, Bulíř, Lane, and Lipschitz (2008) .
} 
conventional Dutch disease effects, these effects are only very temporary and also quite small. Pure foreign aid has no long-run relative price effects, so that it is inappropriate to identify the long-run decline in exports it generates as being a Dutch disease effect. Rather, it is a "current account balance effect", meaning that untied transfers substitute for the production of export goods in financing the purchase of traded consumption goods. ${ }^{7}$

In the case of tied aid, the response of the relative price depends critically on the sectoral allocation of the aid. If it is devoted to enhancing the productivity of the traded sector it will lead to an appreciation of the real exchange rate - the Balassa-Samuelson effect - while if it is allocated to the nontraded sector a real depreciation will result. The mixed allocation of foreign aid may help explain the mixed empirical evidence relating to the impact of aid on the real exchange rate.

While the structural consequences of foreign aid are important, the over-riding issue is its welfare consequences. In this regard, our analysis highlights the tradeoffs that exist between (i) the real exchange rate, (ii) the accumulation of capital (growth), and (iii) the welfare gains associated with aid. Like Adam and Bevan (2006), we find that if the economy starts with a suboptimally low level of public infrastructure, aid directed toward productivity in the nontraded sector tends to deliver the largest welfare benefits. But even when tied aid does lead to real exchange rate appreciation, the resulting loss of competitiveness is dominated by the enhanced productive capacity and the foreign aid is still welfare improving, as it still increases the consumption of both goods. Furthermore, we find that the optimal allocation of aid is to allocate it partially across the alternative uses, a reflection of the diminishing returns to aid, highlighted by Hansen and Tarp (2000).

A key element of the model is that the country, being a developing economy, has restricted access to international capital markets. Creditors insist on securing loans with tangible durable assets, which function as collateral against difficulties in repaying debt on time or default (Kiyotaki and Moore, 1997). We incorporate this by assuming that international capital markets impose a premium on their lending rate to such economies, expressing this as an increasing function of the borrower's ratio of debt to the value of physical assets (Turnovsky, 1997). Including this financial friction enables us to study the country's interaction with foreign private capital markets. We show that the fiscal policy choices and relative capital intensities of nontraded versus traded sectors determine whether the country becomes more or less indebted as a result of aid. This is a relevant policy issue, because

\footnotetext{
${ }^{7}$ The independence of the long-run relative price to untied transfers (a pure demand shock) is an immediate consequence of a basic property of the two-factor two-sector production model, namely that with perfect sectoral factor mobility the long-run relative price depends solely upon supply conditions. A similar result is obtained by Devarajan, Go, Page, Robinson, and Thierfelder (2008). Arellano et al. (2008) generate long-run Dutch disease effects by introducing the imperfect substitutability of capital stocks across sectors. In contrast, untied transfers would continue to have no long-run relative price effects for the form of costly intrasectoral capital flows introduced by Morshed and Turnovsky (2004).
} 
Easterly (2001) has shown that many low income countries have responded to previous rounds of debt relief and higher foreign transfers by accumulating additional private debt.

The two-sector production structure, together with the specification of the financial sector involving increasing debt costs, leads to a macroeconomic equilibrium that is specified by a fourth-order dynamic system. The key equilibrium dynamic variables include: (i) the capital stock, (ii) the stock of debt, (iii) the relative price of non-traded to traded output, and (iv) the shadow value of wealth, expressed in terms of traded output as numeraire.

The macrodynamic equilibrium is fully characterized insofar as possible. The dynamics of two-sector models of this type depend upon the sectoral capital intensities, which in turn have an important bearing on the dynamics of the real exchange rate; see Turnovsky (1997). Being a fourth order system, it must inevitably be analyzed numerically. Thus, much of our analysis is based on a plausible calibration of the model, where we contrast two benchmark cases: (i) the case where the traded sector is relatively capital intensive and (ii) the reverse, using in part sectoral information compiled by Morshed and Turnovsky (2004).

The economy we consider is one having well functioning internal markets and with some access to world financial markets. Thus, our benchmark case is a medium-developed economy such as Turkey, a Latin American economy, or an East-Asian economy. However, in Section $\mathrm{X}$ we also consider the alternative case of highly restricted access to external borrowing that would better characterize many aid-dependent countries in Africa. These presumptions will be reflected in our choice of parameter values employed in the simulations. In choosing these parameters we prefer to set them at typical values for such economies rather than calibrating them to a specific country.

Following this introduction, Sections II and III develop the theoretical model and derive some of its long-run implications. Section IV sets out the numerical calibration, while Sections V-VIII analyze the dynamics of three polar forms of foreign aid: (i) pure aid, (ii) aid tied to productivity in the traded sector, and (iii) aid tied to productivity in the nontraded sector. Section IX briefly addresses some of the welfare consequences and the tradeoff involved, while Section X briefly examines the sensitivity to the costs of debt. Some policy implications are discussed in the final section.

\section{TWO SECTOR MODEL OF FOREIGN AID}

The analysis is based on the following conventional two-sector model of capital accumulation, comprising a traded and non-traded sector, adapted from Turnovsky (1997). The key feature of the model is that the productivity of both sectors depends upon the allocation of government spending it receives in the form of productivity-enhancing nontradeable infrastructure. To preserve tractability these expenditures are introduced as flows, as in Barro (1990), although a natural extenstion would be to specify them as public capital stocks, as in the one-sector analysis of Chatterjee, Sakoulis, and Turnovsky (2003). ${ }^{8}$

\footnotetext{
${ }^{8}$ However, such an extension by involving at least four state variables and corresponding co-state variables would likely be intractable, even using numerical simulations.
} 


\section{A. The Economic Structure}

We consider a small open economy with an infinitely-lived representative agent, who supplies a fixed amount of labor that is normalized to one unit that he sells at the competitive wage. The agent also accumulates capital, $K$, that he rents out at the competitively determined rental rate.

The economy produces a traded good $T$ (the numeraire) using capital, $K_{T}$, and labor, $L_{T}$, by means of the neoclassical production function, $F\left(K_{T}, L_{T}, G_{T}\right)$, where both capital and labor have positive, but diminishing, marginal physical products and are subject to constant returns to scale. In addition, government spending (infrastructure) allocated to the traded sector, $G_{T}$, serves to increase the productivity of that sector, so that $F_{G}>0$.

The economy also employs capital, $K_{N}$, and labor, $L_{N}$ to produce a nontraded good, using the production function, $H\left(K_{N}, L_{N}, G_{N}\right)$, having similar neoclassical properties, and where $G_{N}$ represents the government spending allocated to enhance the productivity of the nontraded sector, $H_{G}>0$. The relative price of nontraded output in terms of the traded output is $p$. It thus serves as a proxy for the real exchange rate, with an increase in $p$ representing a real appreciation. The representative agent takes $p$ as parametrically given, although it is determined by market clearing conditions in the economy.

We assume that the private factors, capital and labor, can be moved instantaneously and costlessly across the two sectors, with the sectoral allocations being constrained by:

$$
\begin{gathered}
K_{T}+K_{N}=K \\
L_{T}+L_{N}=1 .
\end{gathered}
$$

Physical capital is produced in the nontraded sector and depreciates at the rate $\delta_{K}$, thus implying the following capital accumulation constraint:

$$
\dot{K}=I-\delta_{K} K
$$

As discussed by Turnovsky (1997) in detail, the treatment of physical capital as being traded or nontraded has generated substantial debate over the years, although as Brock and Turnovsky (1994) show, restricting capital to be nontraded does not involve a serious loss of generality. $^{9}$

\footnotetext{
${ }^{9}$ Brock and Turnovsky (1994) extend this model to include both traded and nontraded capital.
} 
We assume that the economy can borrow in the international capital market, although being a developing economy, it faces restrictions in doing so. We express this by postulating that the rate of interest at which it may borrow is an increasing function of its debt. This type of constraint was originally proposed by Bardhan (1967) and has been widely adopted since. One issue that arises is whether the specification of debt cost is expressed in terms of its absolute level, as originally proposed by Bardhan, or relative to some earnings capacity to service the debt, as initially argued by Sachs (1984) and others. We adopt the latter, proxying its ability to service the debt by the value of its capital stock that serves as collateral. Thus, we assert that the country can borrow foreign bonds, $N$, at the following endogenous borrowing rate:

$$
r\left(\frac{N}{p K}\right)=r^{*}+\omega\left(\frac{N}{p K}\right) ; \quad \omega^{\prime}>0, \quad \omega^{\prime \prime}>0
$$

where $r^{*}$ is the world interest rate and $\omega(N /(p K))$ is the borrowing premium that increases with the country's stock of debt, $N$, relative to the value of its capital stock, $p K$. In making his individual decisions, the representative agent takes the interest rate as given. This is because the interest rate facing the debtor nation is an increasing function of the economy's aggregate debt, which the individual, being atomistic, rationally assumes he is unable to influence. ${ }^{10}$

Given this access to the world goods and financial markets, the domestic agent's instantaneous budget constraint is specified by:

$$
\dot{N}=C_{T}+p C_{N}+p\left(\dot{K}+\delta_{K} K\right)+p T-F\left(K_{T}, L_{T}, G_{T}\right)-p H\left(K_{N}, L_{N}, G_{N}\right)+r\left(\frac{N}{p K}\right) N
$$

where $C_{T}$ and $C_{N}$ are the agent's consumption of the traded and nontraded goods, and $T$ denote domestic taxes which we take to be lump-sum and denominated in terms of nontraded output.

The representative agent chooses his consumption levels, $C_{T}$ and $C_{N}$; sectoral labor allocation, $L_{T}$ and $L_{N}$; sectoral capital allocation, $K_{T}$ and $K_{N}$, and the rates of accumulation of capital and debt, $\dot{K}$ and $\dot{N}$, to maximize the intertemporal utility function:

$$
\Omega \equiv \int_{0}^{\infty} U\left(C_{T}, C_{N}\right) e^{-\rho t} d t
$$

\footnotetext{
${ }^{10}$ The equilibrium and implications are also insensitive to variations in the specification of (3), that replace $N / p K$ with expressions such as $N / Y$ (output) or $N / W$ (wealth); see e.g. Chatterjee, Sakoulis, and Turnovsky (2003).
} 
subject to the constraints (1)-(4) and given initial stocks of assets $K(0)=K_{0}$ and $N(0)=N_{0}$. The instantaneous utility function is assumed to be concave and the two consumption goods are assumed to be normal. The agent's rate of time preference, $\rho$, is constant.

This is a standard intertemporal optimization problem and yields the optimality conditions:

$$
\begin{gathered}
U_{T}\left(C_{T}, C_{N}\right)=\mu \\
U_{N}\left(C_{T}, C_{N}\right)=\mu p \\
\frac{1}{p} F_{K}\left(K_{T}, L_{T}, G_{T}\right)=H_{K}\left(K_{N}, L_{N}, G_{N}\right) \\
\frac{1}{p} F_{L}\left(K_{T}, L_{T}, G_{T}\right)=H_{L}\left(K_{N}, L_{N}, G_{N}\right) \equiv w \\
\rho-\frac{\dot{\mu}}{\mu}=r\left(\frac{N}{p K}\right) \\
\frac{F_{K}\left(K_{T}, L_{T}, G_{T}\right)}{p}+\frac{\dot{p}}{p}-\delta_{K}=r\left(\frac{N}{p K}\right)
\end{gathered}
$$

together with the transversality conditions that must hold to ensure that the agent's intertemporal budget constraint is met:

$$
\lim _{t \rightarrow \infty} \mu N e^{-\rho t}=0 ; \lim _{t \rightarrow \infty} \mu p K e^{-\rho t}=0 .
$$

where $\mu$, the Lagrange multiplier associated with (4), is the shadow value of wealth.

Equations (6a) and (6b) equate the marginal utility of consumption to the shadow value of wealth, appropriately measured in terms of the numeraire. Equations (6c) and (6d) determine the sectoral allocation decisions by equating the marginal physical products of the two factors across the two sectors. Equations (6e) and (6f) are arbitrage conditions equating the rate of return on consumption and the rate of return on nontraded capital to the borrowing cost.

The government has two sources of revenue, lump-sum taxes, $T$, collected from domestic residents, and foreign transfers, $T R$, denominated in units of traded output. These resources may be used to enhance the productivity of the traded sector, $G_{T}$, or the nontraded sector, $G_{N}$ as reflected in the balanced budget 


$$
G_{T}+G_{N}=T+\frac{T R}{p}
$$

This equation also implies that the direct effect of untied foreign aid is to reduce the tax burden of domestic residents. ${ }^{11}$

The economy starts from an equilibrium with zero transfers, so that initially all expenditures are financed using lump-sum taxation:

$$
G_{T, 0}+G_{N, 0}=T_{0}
$$

At time 0 , the government receives a permanent foreign aid transfer, $T R$, which is allocated toward $G_{T}, G_{N}, T$ in accordance with:

$$
\begin{gathered}
G_{T}(t)=G_{T, 0}+\lambda(1-\phi) \frac{T R}{p(t)} \\
G_{N}(t)=G_{N, 0}+\lambda \phi \frac{T R}{p(t)} \\
T(t)=T_{0}-(1-\lambda) \frac{T R}{p(t)}
\end{gathered}
$$

Thus, $\lambda$ parameterizes the allocation of the transfer between tax reduction and an increase in expenditures, while $\phi$ specifies the allocation of the expenditures between the two sectors. With the transfer specified in terms of the traded good, the resources available to spend on productivity-enhancing infrastructure vary inversely with the evolving relative price, $p(t)$.

The final two equations are the economy's accumulation equations. Nontraded goods market equilibrium requires:

$$
\dot{K}=H\left(K_{N}, L_{N}, G_{N}\right)-C_{N}-\left(G_{T}+G_{N}\right)-\delta_{K} K
$$

That is, any nontraded output in excess of domestic private consumption, government purchases, and the stock of capital that has depreciated, is accumulated as nontraded capital. This equation, together with the private sector budget constraint, (4), and the government budget constraint, (8), yields the current account equation for the economy:

$$
\dot{N}=C_{T}-F\left(K_{T}, L_{T}, G_{T}\right)+r\left(\frac{N}{p K}\right) N-T R
$$

\footnotetext{
${ }^{11}$ We are assuming that the foreign aid denominated in units of traded output can be costlessly converted to nontraded output. We also abstract from issues pertaining to the theft of aid by corrupt government officials.
} 
The rate of debt accumulation equals the excess of domestic private consumption of the traded good over its supply, plus the interest owed on the existing stock of debt, less the transfers received.

\section{B. Macroeconomic Equilibrium}

The linear homogeneity of the production functions in the private factors allows us to express relations in terms of sectoral capital-labor ratios. Thus, defining $k_{i} \equiv K_{i} / L_{i}$ to be the capitallabor ratio in sector $i$, where $i=T, N$, the corresponding production functions can be expressed as

$$
f\left(k_{T}\right) \equiv F\left(K_{T}, L_{T}, G_{T}\right) / L_{T}, h\left(k_{N}\right) \equiv H\left(K_{N}, L_{N}, G_{N}\right) / L_{N} .
$$

This enables us to summarize the macroeconomic equilibrium by the following set of relationships:

$$
\begin{gathered}
U_{T}\left(C_{T}, C_{N}\right)=\mu \\
U_{N}\left(C_{T}, C_{N}\right)=\mu p \\
f_{k}\left(k_{T}, G_{T}\right)=p h_{k}\left(k_{N}, G_{N}\right) \\
f\left(k_{T}, G_{T}\right)-k_{T} f_{k}\left(k_{T}, G_{T}\right)=p\left[h\left(k_{N}, G_{N}\right)-k_{N} h_{k}\left(k_{N}, G_{N}\right)\right] \\
L_{T} k_{T}+\left(1-L_{T}\right) k_{N}=K \\
\dot{K}=\left(1-L_{T}\right) h\left(k_{N}, G_{N}\right)-C_{N}-\left(G_{N}+G_{T}\right)-\delta_{K} K \\
\dot{N}=C_{T}-L_{T} f\left(k_{T}, G_{T}\right)+r(.) N-T R \\
\dot{p}=p\left[r(.)+\delta_{K}-h_{k}\left(k_{N}, G_{N}\right)\right] \\
\frac{\dot{\mu}}{\mu}=\rho-r\left(\frac{N}{p K}\right)
\end{gathered}
$$

together with the allocation of the transfers as specified by (9).

From this macroeconomic equilibrium, we see that the real exchange rate, $p$, plays two economic roles. First, it functions as a relative price of nontraded to traded goods, which impacts the demand for the two goods. But in addition it serves as an asset price, inducing factor inputs to shift across sectors. In particular it is a component of the arbitrage conditions equating the rate of return on capital in the traded and nontraded sectors to the cost of borrowing [see equations (12c), (13c)]. 
Equations (12a)-(12e) define the short-run equilibrium and follow the conventional block recursive structure as laid out for example in Turnovsky and Sen (1995). First, the marginal utility, conditions (12a) and (12b), can be solved for the two consumption levels, $C_{T}$ and $C_{N}$, in the form

$$
\begin{aligned}
& C_{T}=C_{T}(\mu, p) \\
& C_{N}=C_{N}(\mu, p)
\end{aligned}
$$

where $^{12}$

$$
\frac{\partial C_{T}}{\partial \mu}<0 ; \quad \frac{\partial C_{T}}{\partial p} \frac{\geq}{<} 0 ; \quad \frac{\partial C_{N}}{\partial \mu}<0 ; \quad \frac{\partial C_{N}}{\partial p}<0 .
$$

Second, the production block (12c) and (12d), together with the factor allocation (12e) yield

$$
\begin{gathered}
k_{T}=k_{T}\left(p, G_{T}, G_{N}\right) \\
k_{N}=k_{N}\left(p, G_{T}, G_{N}\right) \\
L_{T}=L_{T}\left(K, p, G_{T}, G_{N}\right)
\end{gathered}
$$

where the signs of the partial derivatives of (15a) - (15c) are reported in the Appendix. To the extent that $G_{N}, G_{T}$ are functions of $p(t)$, through the spending allocations in (9), the full effect of $p(t)$ on capital intensities needs to take this into account. As is familiar from twosector trade models, the qualitative responses summarized in the Appendix depend upon the sectoral capital intensities. For example, a rise in the relative price of the nontraded good, holding $G_{T}$ and $G_{N}$ constant, will cause resources to move from the traded to the nontraded sector, consistent with the Dutch disease effect. If the latter sector is more capital intensive, capital increases in relative scarcity, causing the wage-rental ratio to fall and inducing the substitution of labor and capital in both sector; i.e. $k_{T}, k_{N}$ both decline.

Substituting (15a)-(15c) into the production functions, we may express traded and nontraded outputs in the form

$$
X=L_{T} f\left(k_{T}, G_{T}\right)=X\left(K, p, G_{T}, G_{N}\right)
$$

\footnotetext{
12 The conditions $\partial C_{T} / \partial \mu<0, \partial C_{N} / \partial \mu<0$ are a statement of the normality of the two consumption goods, while $\partial C_{N} / \partial p<0$ follows from the concavity of utility. Also, $\operatorname{sgn}\left(\partial C_{T} / \partial p\right)=-\operatorname{sgn}\left(U_{T N}\right)$.
} 


$$
Y=\left(1-L_{T}\right) h\left(k_{N}, G_{T}\right)=Y\left(K, p, G_{T}, G_{N}\right)
$$

where the partial derivatives of (16a) and (16b) are reported in the Appendix. As the capital stock rises, production increases in the capital intensive sector and falls in the labor intensive sector. Holding $G_{T}$ and $G_{N}$ constant, as the real exchange rate appreciates, traded production falls and nontraded production rises.

\section{STEADY STATE EQUILIBRIUM}

Substituting (14) and (15) into (13) yields an autonomous dynamic equilibrium determining the evolution of $K, N, p, \mu$, which forms the basis for our numerical simulations. Before discussing this, we shall briefly consider the steady state, attained when $\dot{K}=\dot{N}=\dot{p}=\dot{\mu}=0$. To accomplish our objective of considering the long-run consequences of foreign aid (and its alternative allocations), it is convenient to summarize it by the sets of relationships:

\section{Sectoral Allocation Relationships}

$$
\begin{gathered}
h_{k}\left(\tilde{k}_{N}, G_{N}\right)-\delta_{K}=\rho \\
f_{k}\left(\tilde{k}_{T}, G_{T}\right)=\tilde{p} h_{k}\left(\tilde{k}_{N}, G_{N}\right) \\
f\left(\tilde{k}_{T}, G_{T}\right)-\tilde{k}_{T} f_{k}\left(\tilde{k}_{T}, G_{T}\right)=\tilde{p}\left[h\left(\tilde{k}_{N}, G_{N}\right)-\tilde{k}_{N} h_{k}\left(\tilde{k}_{N}, G_{N}\right)\right]
\end{gathered}
$$

\section{Aggregate Market-Clearing Relationships}

$$
\begin{gathered}
\tilde{p} U_{T}\left(\tilde{C}_{T}, \tilde{C}_{N}\right)=U_{N}\left(\tilde{C}_{T}, \tilde{C}_{N}\right) \\
\tilde{L}_{T} \tilde{k}_{T}+\left(1-\tilde{L}_{T}\right) \tilde{k}_{N}=\tilde{K} \\
\left(1-\tilde{L}_{T}\right) h\left(\tilde{k}_{N}, G_{N}\right)-\tilde{C}_{N}-\left(G_{N}+G_{T}\right)-\delta_{K} \tilde{K}=0 \\
\tilde{C}_{T}+\rho \tilde{N}=\tilde{L}_{T} f\left(\tilde{k}_{T}, G_{T}\right)+T R \\
r\left(\frac{\tilde{N}}{\tilde{p} \tilde{K}}\right)=\rho
\end{gathered}
$$

Equations (17a)-(17c), (18a)-(18e) determine the steady-state values (denoted by tildes); $\tilde{k}_{N}, \tilde{k}_{T}, \tilde{p}, \tilde{C}_{T}, \tilde{C}_{N}, \tilde{L}_{T}, \tilde{K}, \tilde{N}$ in terms of given allocations for $G_{T}, G_{N}$, and $T R$ as determined by (9a) - (9c). Written this way, the solution reflects the recursive structure of the steadystate equilibrium that is characteristic of the two-sector trade model. 
First, given $G_{N}$, (17a) determines the capital-labor ratio in the non-traded sector such that the rate of return on capital in that sector equals the given rate of time discount. Given $\tilde{k}_{N}$, allocation efficiency then determines $\tilde{k}_{T}$ and the relative price $\tilde{p}$. Thus, taken together, (17a) $-(17 \mathrm{c})$ imply

$$
\begin{aligned}
& \tilde{k}_{N}=\tilde{k}_{N}\left(G_{N}\right) \\
& \tilde{k}_{T}=\tilde{k}_{T}\left(G_{T}, G_{N}\right) \\
& \tilde{p}=\tilde{p}\left(G_{T}, G_{N}\right)
\end{aligned}
$$

Hence, foreign aid will have long-run effects on the sectoral capital-labor ratios and relative price if and only if it is tied to productive government spending.

Intuition for the invariance of the long-run real exchange rate in the face of untied aid flows follows from equations (17a) - (17c). First, (17a) equates the rate of return on capital in the nontraded sector to the rate of time preference, thus determining capital intensity in the nontraded goods sector independently of untied aid flows. Second, dividing (17b) by (17c), sectoral factor mobility ensures the equality of the wage-rental ratio across sectors, thus determining the capital intensity in the traded goods sector and the marginal product of capital in that sector. Finally with perfect sectoral capital mobility the real exchange rate equals the ratio of the marginal products both of which are independent of untied aid flows.

Given $\tilde{k}_{N}, \tilde{k}_{T}$, and $\tilde{p}$ from (18a)-(18e) we can express the solutions for $\tilde{C}_{T}, \tilde{C}_{N}, \tilde{L}_{T}, \tilde{K}, \tilde{N}$, as well as output levels, $\tilde{X}, \tilde{Y}$, and GNP, $\tilde{Z} \equiv \tilde{X}+\tilde{p} \tilde{Y}$, in the form:

$$
\tilde{\Omega}=\Omega\left(T R, G_{T}, G_{N}, \tilde{k}_{N}\left(G_{N}\right), \tilde{k}_{T}\left(G_{N}, G_{T}\right), \tilde{p}\left(G_{N}, G_{T}\right)\right) \quad \tilde{\Omega} \equiv\left(\tilde{C}_{T}, \tilde{C}_{N}, \tilde{L}_{T}, \tilde{K}, \tilde{N}, \tilde{X}, \tilde{Y}, \tilde{Z}\right)
$$

Written this way emphasizes the different channels whereby foreign aid impacts the long-run equilibrium. First, the effect of untied aid is simply $\partial \tilde{\Omega} / \partial(T R)$. But to the extent that aid is tied, it has several other effects, both indirect and direct. The former operate through the impact on the sectoral capital intensities and relative prices as in (19). The direct effects operate through their impact on excess demand through the market clearing conditions (18c) and (18d).

\section{A. Long-Run Effects of Transfers on the Relative Price}

From (17a) - (17c) it is straightforward to determine the effect of a transfer on the relative price of nontraded to traded goods. To do this we first express the long-run changes in government allocations due to the transfers in the form:

$$
d \tilde{G}_{T}=\lambda(1-\phi) \frac{d T R}{\tilde{p}}
$$




$$
\begin{gathered}
d \tilde{G}_{N}=\lambda \phi \frac{d T R}{\tilde{p}} \\
d \tilde{T}=-(1-\lambda) \frac{d T R}{\tilde{p}}
\end{gathered}
$$

(where we assume an initial equilibrium of zero transfers) and combine these with (18c), (18d), and (20). Omitting details, we obtain the following effect on the long-run relative price:

$$
\frac{d \tilde{p}}{d(T R)}=\frac{\lambda\left[(1-\phi) f_{G}-\phi \tilde{p} h_{G}\right]}{f}
$$

This equation indicates the factors that determine whether or not a foreign aid increase is associated with a long-run appreciation of the real exchange rate. This depends upon the allocation parameters, $\lambda, \phi$, as well as the impact of the transfer on the productivities of the two sectors. If $\lambda=0$ the transfer is devoted entirely to tax reduction and is thus a pure demand effect. It therefore has no long-run effect on the relative price, although as we shall see in the simulations it does have a slight temporary transitional effect.

To the extent that aid is allocated to the traded sector and raises its productivity it will raise the long-run relative price of nontraded goods and lead to an appreciation of the recipient country's exchange rate. This is a standard Balassa-Samuelson effect, arising from a relative increase in the productivity of the traded sector. To the extent that the aid is granted to the nontraded sector it will lower the long-run relative price of nontraded goods and lead to a real depreciation of the exchange rate. Thus, foreign aid that is allocated to enhancing productivity is not inevitably associated with a long-run appreciation of the exchange rate; it depends upon its sectoral allocation.

\section{B. Transfers, Economic Activity, and the Dutch Disease}

Since untied aid has no effect on relative prices or sectoral capital intensities, its complete effect is easily obtained by computing $\partial \tilde{\Omega} / \partial(T R)$ from (20). The formal expressions are reported in the Appendix. Being a net transfer of traded resources to the economy, foreign aid generates a rise in wealth, the marginal utility of which therefore declines. Since traded and nontraded goods are both normal and their relative price remains unchanged, the consumption of both goods increase proportionately. Because nontraded goods are produced using only domestic resources, labor and capital must both shift from the traded to the nontraded sector, leading to a reduction of output in the former and an increase in the latter. In contrast, being denominated in terms of the traded good, aid directly increases the opportunity for more traded consumption. That is, the rise in consumption demand for traded goods can be met directly through imports, without an expansion in domestic traded production. The net effect on GNP is ambiguous, depending upon which effect dominates. 
With relative prices remaining unchanged in the long run, capital and debt must change proportionately in order for the long-run borrowing rate to remain equal to the given rate of time preference. Whether these both increase or decrease depends upon the relative capital intensities of the two sectors. With resources being moved to the nontraded sector, capital and debt will decline (increase) if and only if $k_{T}>k_{N}\left(k_{N}>k_{T}\right)$.

One issue to receive extensive discussion is whether or not foreign aid is associated with the Dutch disease; see e.g Arellano et al. (2008). This term refers to a situation where the foreign aid leads to an appreciation of the real exchange rate, resulting in a decline in the traded output $X=L_{T} f\left(k_{T}, G_{T}\right)$. While pure foreign aid is associated with a long-run decline in traded output, this is not due to any movement in the real exchange rate, which remains unchanged in the long run. We therefore do not identify this as Dutch disease. Basically the decline in the traded sector is a consequence of the long-run current account balance, (18d). On the left-hand side of this equation we have the country's international obligations, namely its purchase of traded consumption plus debt servicing costs, while on the right hand side we have its sources of finance. Given demand, the larger the transfers the less the need to produce traded output, and the more resources can be allocated to the nontraded sector.

There is, however, a short-run Dutch disease problem. Differentiating (16a), we see that with $K$ pre-determined, the immediate effect of untied foreign aid on traded output is given by

$$
\frac{\partial X}{\partial T R}=\frac{\partial X}{\partial p} \frac{\partial p}{\partial T R}
$$

As our simulations demonstrate, the transfer is associated with an immediate appreciation of the real exchange rate, the effect of which is to reduce the size of the traded sector in the conventional way. These effects are generally small, although they increase as the country's access to international capital markets declines [see Fig. 5.1, (A) and (B)]. Finally, we may point out that tied transfers, which are associated with allocations of public expenditures across the sectors, will lead to complex effects on sectoral resource allocation, both directly, and through their impact on relative prices and sectoral capital intensities. These include the standard Balassa-Samuelson effect.

\section{NUMERICAL ANALYSIS}

To study the dynamic evolution of the economy, we substitute the solutions for $C_{T}, C_{N}, k_{T}, k_{N}$ and $L_{T}$ into (13a)-(13d), and linearize the resulting system about its steady state. For there to be a unique stable adjustment path, it must have two stable and two unstable eigenvalues. With the capital stock, $K$, and the national debt, $N$, evolving gradually, this is achieved by instantaneous jumps in the shadow value of wealth, $\mu$, and the real exchange rate, $p$.

The complexity of the model renders it intractable to solve analytically, and thus, we will study the dynamic effects of a permanent increase in foreign aid using numerical simulations. The functional forms we employ are: 


$$
\begin{gathered}
U=(1 / \gamma) C_{T}^{\gamma \theta} C_{N}^{\gamma(1-\theta)} ; 0<\theta<1, \quad-\infty<\gamma<1 \\
X=A K_{T}^{\alpha} L_{T}^{1-\alpha} G_{T}^{v_{1}} ; 0<\alpha<1 \\
Y=B K_{N}^{\beta} L_{N}^{1-\beta} G_{N}^{v_{2}} ; 0<\beta<1 \\
r=r^{*}+\xi e^{a(N / p K)}
\end{gathered}
$$

where $1 /(1-\gamma)$ is the intertemporal elasticity of substitution, $\theta$ reflects the relative importance of traded versus nontraded goods in overall consumption, and $\alpha, \beta$ characterize the respective degrees of capital intensity in the two sectors.

\section{A. Calibration}

We calibrate a benchmark economy using the parameters summarized in Table 1, representing a typical small open economy. Since the dynamics of a two-sector dependent economy model depend on the relative sectoral capital intensities, we consider two different scenarios: Case I where the traded sector is more capital intensive than the nontraded sector ( $\alpha>\beta$ ), and Case II where it is less capital intensive $(\alpha<\beta)$. ${ }^{13}$ The preference parameters $\gamma, \theta, \rho$ are standard, while the production parameters $\alpha, \beta$ and the productivity parameters $A, B$ are chosen to ensure a plausible equilibrium labor share in the traded sector. ${ }^{14}$ The borrowing premium $a=0.1$ and the weight on the borrowing premium $\xi$ are chosen in order to attain a plausible debt to output ratio close to the debt to output ratio of low income countries ${ }^{15}$. Because access to world financial markets is an important aspect of our study, we conduct sensitivity analysis with respect to $a$, allowing it to vary between $a=0.01$ (easy access), $a=0.1$ (medium access) and $a=10$ (highly restricted access); see Figs. 5-7. ${ }^{16}$ The base values of the traded and nontraded government expenditures are initially set to $G_{T}=0.05$ and $G_{N}=0.17$, respectively and are subject to change to the extent

\footnotetext{
${ }^{13}$ In all cases the equilibrium possesses the saddlepoint structure necessary to yield a unique stable adjustment path.

${ }^{14}$ The choice of parameters, particularly those relating to the sectoral aspects, are discussed in greater detail by Morshed and Turnovsky (2004). Our choice of elasticities on government expenditures in production, $v_{1}=0.10, v_{2}=0.15$ imply that government expenditure is more productive in producing nontraded than traded output, which includes services. While this is arbitrary, it is not implausible, and in any event our numerical results are insensitive to this assumption.

${ }^{15}$ The World Bank Group, World Development Indicators Online reports the average external debt total (\% of GNP), for the lower middle income Latin America and Caribbean countries, excluding Guyana and Nicaragua, to lie within the range of $60-65 \%$. Our benchmark estimates of this ratio given by $N / Z$ in Table 3 are very close to this range.

${ }^{16}$ Further increases in $a$ beyond $a=10$ have negligible effects except on the level of debt.
} 
that foreign aid is allocated toward them in accordance with (9). Because we are assuming that the economy is in need of foreign aid, and therefore presumably starts below its optimum, the choice of these base spending values is crucial. To ensure that they are chosen plausibly, we must first determine the optimal steady-state levels of government spending.

\section{B. Optimal Government Spending}

To determine optimal government spending we assume that the government, operating as a central planner and starting out with zero transfers, chooses $G_{T}$ and $G_{N}$ to maximize the welfare of the representative agent, subject to (i) the nation's current account, (11), its accumulation of capital, (10), and resource allocation constraints, (1a)-(1b). Omitting details, the two sets of benchmark parameters yield the following. In Base Case I, ( $\alpha=0.35, \beta=0.25$ ), the welfare-maximizing levels of traded and nontraded government spending are $\hat{G}_{T}=0.079$, and $\hat{G}_{N}=0.196$. For Base Case II, $(\alpha=0.25, \beta=0.35)$, the corresponding optimal levels of government spending are much higher, namely $\hat{G}_{T}=0.118$, and $\hat{G}_{N}=0.300$. Thus, our chosen benchmark values of traded and nontraded government spending levels of 0.05 and 0.17 , are below their respective optimal levels, substantially so in Case II. This ensures that we are dealing with an economy that indeed has serious resource constraints and requires aid in order to increase the economy's productive capacity in both sectors. ${ }^{17}$

\section{Initial Benchmark Equilibria}

Substituting the benchmark parameters into the steady-state equations (17a)-(17c) and (18a)(18e) and into the functional form for (22d) yields the benchmark equilibrium values summarized in Table 2. Panel A reports the key steady-state equilibrium ratios for Case I, when the traded sector is more capital intensive. The sectoral capital-output ratios in the traded and nontraded sectors are 3.5 and 2.5, respectively, yielding an overall capital-output ratio of 2.89. The traded sector produces $39 \%$ of total output, and employs $36 \%$ of labor. The long-run relative price of nontraded good is 1.365 . Table $1(\mathrm{~B})$ reports the key steady state equilibrium ratios in the second scenario where the nontraded sector is more capital intensive. The sectoral capital-output ratios in the traded and nontraded sectors are 2.5 and 3.5, respectively, yielding an overall capital-output ratio of 3.1. The traded sector produces slightly more of total output and employs slightly more labor than in the case where the traded sector is capital intensive. The long-run relative price of nontraded good is $0.922 .{ }^{18}$

\footnotetext{
${ }^{17}$ Adam and Bevan (p. 275, 2006) follow a similar strategy and assume that initial public infrastructure is 50\% of its optimal value. We have also run the simulations reported in Section V-X starting from the initial optimal allocation of government spending. The time paths are virtually identical to those presented in Figs. 1-4.

18 These calibrations are consistent with the economic structures of developing countries summarized by Morshed and Turnovsky (2004).
} 


\section{FOREIGN AID FLOWS: GENERAL CHARACTERISTICS OF REAL EXCHANGE RATES}

Starting from these initial equilibria, we analyze the economic impact and welfare consequences of the three allocations of foreign aid, namely debt reduction vs. increased productive government spending in either sector. We set the size of the permanent aid transfer to 0.15 units of traded output, which equals about $5 \%$ of baseline GDP. ${ }^{19}$ We analyze the long-run effects and transitional dynamics generated by those shocks, as summarized in Table 3 and Figs. 1-4.

From Fig. 2, we see that in all cases the real exchange rate responds virtually instantaneously to the aid shock. To understand this we focus on the arbitrage equation (13c) in the polar case of (i) no borrowing premium and (ii) pure transfer, so that $G_{T}, G_{N}$ remain fixed (denoted by bars). In that case, the relative price follows the autonomous equation

$$
\dot{p}=p\left[r^{*}+\delta_{K}-h_{k}\left(k_{N}\left(p, \bar{G}_{N}, \bar{G}_{T}\right), \bar{G}_{N}\right)\right]
$$

the linear approximation to which is

$$
\dot{p}=\frac{f}{\tilde{p}\left(\tilde{k}_{T}-\tilde{k}_{N}\right)}(p-\tilde{p})
$$

If the traded sector is more capital intensive, this equation is unstable and the only finite time path for $p(t)$ is $p(t)=\tilde{p}$; there are no transitional dynamics in $p(t)$ [see Turnovsky, 1997]. If $\tilde{k}_{N}>\tilde{k}_{T}$, (23) implies a stable adjustment and therefore transitional dynamics exist in principle. However, for the chosen parameter set, the coefficient in (23) is around 0.65, which implies incredibly fast adjustment to steady state. This is a consequence of the choice of the production elasticities, $\alpha, \beta$, which cannot deviate too much in order for the implied sectoral returns to capital to remain plausible. This in turn limits the potential differences in sectoral capital intensities, $\left(k_{T}-k_{N}\right)$, thus forcing the relative price to adjust rapidly. ${ }^{20}$

With increasing borrowing costs $\left[r^{\prime}>0\right]$ and the price effects associated with tied aid, other elements also come into play. Nevertheless, the pure effect described by (23) still dominates, and as a result, the real exchange rate always remains close to its (new) steady state, irrespective of sectoral capital intensities. In the case of the pure transfer, when the long-run real exchange rate remains unchanged, the short-run real exchange rate remains virtually unchanged as well. As access to the world capital market declines, the adjustment of the real

\footnotetext{
${ }^{19}$ This is close to average aid flows for Latin American countries. The World Bank Group, World Development Indicators Online reports the average Aid (\% of GNP), for the lower middle income Latin America and Caribbean countries to be about $5 \%$.

${ }^{20}$ The speed of adjustment of the real exchange rate slows dramatically and the significance of the transitional path enhanced by introducing adjustment costs on sectoral capital movements; see Morshed and Turnovsky (2004).
} 
exchange rate slows down and the transitional phase becomes more pronounced; see Figs. 5.1- 7.1.

\section{Pure transfer}

This represents a tax reduction that decreases the rate of debt accumulation, thereby facilitating increased consumption of privately provided traded and nontraded goods. It corresponds to a pure demand shock and provides a convenient benchmark for understanding the economic impact of an exogenous rise in wealth and observing the role of sectoral capital intensities. The formal expressions for the long-run responses are reported in the Appendix and have been discussed. The numerical results presented for the pure transfer in Table 3 confirm these qualitative responses.

\section{A. Traded Sector is Capital Intensive: $(\alpha>\beta)$}

The resulting increase in wealth immediately raises the demand for both traded and nontraded consumption [see Figs. 4.1, 4.2]. Both capital and labor must immediately shift from the traded to the nontraded sector, in order to provide the necessary additional nontraded output. Because the nontraded sector uses relatively less capital than does the traded sector, the economy initially has an excess of capital, which it gradually reduces over time [Fig. 1.1]. Following its initial shift to the nontraded sector, labor continues its move to that sector over time. This is because the nontraded sector initially substitutes some of the economy's excessive capital for labor. Indeed, during the transition the capital-labor ratios in both sectors are above their steady-state values. ${ }^{21}$ Since the transitional labor share of the traded sector, $L_{T}$, exceeds its new steady-state value, and since the economy discards capital only gradually, domestic production of traded output initially exceeds its long-run level and continues to decline gradually over time, as the economy adjusts.

For reasons noted, the real exchange rate remains close to its (unchanged) steady-state value, although there is some slight initial appreciation, which can only be detected in Fig. 5.1. Since the nontraded sector is labor intensive, the transitional rise in the relative price of nontraded goods generates a rise in the wage rate (Stolper-Samuelson Theorem) and fall in the return to capital. Although a fraction of both labor and capital move to the nontraded sector, the decline in the rental rate of capital induces some substitution toward capital, and thus more capital shifts to the nontraded sector relative to the shift in labor. The decline in the return to capital also provides the incentive for the required reduction of capital over time, although the movement in the return to capital is slight. Starting at 5\% it drops rapidly to $4.95 \%$ before gradually rising back to its initial equilibrium.

The direct effect of the transfer is to reduce the rate of debt accumulation, which initially declines rapidly. However, the reduction in traded output, coupled with the increase in traded consumption, offsets this initial decline and after approximately four periods debt starts to

\footnotetext{
${ }^{21}$ We illustrate the capital intensity only in the traded sector, since both $k_{N}$ and $k_{T}$ move together.
} 
increase, although with the higher capital stock it falls short of its initial pre-aid level. With capital and debt eventually decreasing by the same proportionate amount, the pure transfer has little effect on wealth following the initial transfer, which actually declines slightly over time. Hence with the price remaining virtually unchanged, both traded and nontraded consumption remain virtually constant during the transition. The initial increase in consumption resulting from the transfer immediately boosts welfare, although it declines slightly over time, reflecting the slight decline in wealth.

\section{B. Nontraded sector is capital intensive: $(\beta>\alpha)$}

As before, the initial response is to increase the demand for both consumption goods, requiring both factors to immediately shift from the traded to the nontraded sector in order to provide the necessary increase in nontraded output. The real exchange rate initially appreciates slightly [see Fig. 5.1], which reduces the borrowing costs and further raises the demand for traded consumption. This causes debt to increase initially, [see Fig. 1.2(B)], although this is partially reversed over time. In addition, with the nontraded sector being capital intensive, the total capital stock increases over time to a new higher steady-state level. This causes the transitional dynamics to be reversed from the previous case, where $\alpha>\beta$, and the underlying intuition can be inferred from the previous analysis. One point to note is that the capital intensity of the nontraded sector amplifies the steady-state expansion of the nontraded sector. This is because the larger capital stock, $\tilde{K}$, generates a greater need for nontraded output to replace the depreciating capital stock.

\section{PRoductive governMent SPENDING IN THE TRADED SECTOR}

Foreign aid tied to productive government spending in the traded sector acts as a favorable supply shock to that sector. The relative price of traded goods falls, or equivalently, the longrun real exchange rate appreciates, regardless of the sectoral capital intensities, as for the Balassa-Samuelson effect [see Tied Transfer $(\lambda=1, \phi=0)$ in Table 3 ]. For Cobb-Douglas production functions, this productivity shock raises the marginal products of both capital and labor in producing traded output proportionately, thus increasing traded output for given factor inputs, and enhancing the output flow from available resources in the economy. This increases the representative agent's wealth even though aid is not transferred directly to the agent as income subsidies or tax cuts.

The equilibrium conditions (17b) and (17c) imply that for Cobb-Douglas production functions, proportional shifts in the marginal products of all inputs lead to proportional adjustments in the capital-labor ratio in both sectors. Hence, with the steady-state capital intensity in the nontraded sector, $\tilde{k}_{N}$, being determined in that sector alone [see (17a)] (independent of productivity shifts in the traded sector), the capital intensity in the traded sector, $\tilde{k}_{T}$, remains unchanged as well.

The long-run real exchange rate appreciates by about 11.5\%-14.5\% (depending on relative sectoral capital intensities). The relative price of the nontraded good rises in order to equate the sectoral rates of return. The higher real exchange rate boosts the value of the capital that 
is used as collateral, supporting a larger external debt for a given capital stock. Indeed, the steady-state level of debt rises regardless of sectoral capital intensities. In addition, the higher real exchange rate increases the value of nontraded output, so that steady-state GDP in units of traded goods is higher for both cases of capital intensity. On the other hand, the high relative price of nontraded goods causes a shift in consumption demand away from nontraded goods. Therefore, whereas steady-state consumption of traded goods rises significantly, nontraded consumption changes little.

\section{A. Traded sector is capital intensive $(\alpha>\beta)$}

As for the pure transfer, the shift of factors to the nontraded sector implies that the economy has excessive capital. But because the tied aid raises the productivity of traded production, the economy can now afford to discard even more capital, and indeed, the capital stock declines more in this scenario than for the pure transfer [see Fig. 1.1]. The appreciation of the real exchange rate raises the value of the capital stock used as collateral, leading to a higher level of steady-state debt, compared to the pure transfer [see Fig. 1.2]. This immediately reduces the borrowing by 0.2 percentage points, thereby immediately encouraging the accumulation of debt, and increasing traded consumption by a larger amount than for an untied transfer [see Fig. 4.1]. With capital declining, debt increasing, and therefore wealth declining, after their initial increases, consumption and welfare decline, doing so at a faster rate than for a pure transfer [see Fig. 4.3].

\section{B. Nontraded sector is capital intensive $(\beta>\alpha)$}

In this case the economy must accumulate capital to support increased nontraded production [see Fig. 1.1(B)]. With capital being relatively scarce and taking time to accumulate the nontraded sector must initially attract labor from the traded sector to substitute for capital [see Fig. 3.1(B)]. This involves some mild overshooting of the labor adjustment and causes sectoral capital intensities initially to decline. But since in the long run capital intensities must return to their original levels, capital accumulation has to make up for the initial overshooting of labor in the nontraded sector, thus increasing rapidly initially and then slowing down as some of the labor returns back to the traded sector. This leads to mild overshooting of the capital stock during the transition.

Allocating aid to the traded sector raises factor productivity in that sector, thereby offsetting the initial shift of labor and capital to the nontraded sector. Traded consumption slightly overshoots its new higher steady-state level [Fig. 4.1(B)]. The debt level rises with the accumulation of capital and the higher value of the capital stock (due to the rise in $p$ ). The real exchange rate slightly overshoots its long-run value, but the magnitude is small and quickly eliminated. The other dynamic responses to the government spending in the traded sector depend on the relative capital intensities. However, other than the effects mentioned above, the responses mirror the case of a pure transfer. 


\section{Productive governMent SPENDING IN THE NONTRADED SECTOR}

As in previous cases, this transfer increases the demand for both consumption goods, requiring resources to move to the nontraded sector. But in other respects, aid devoted to enhancing productivity of the nontraded sector has strikingly different consequences, as can be seen from Table 3 and Figs. 1-4. As a favorable supply shock to the nontraded sector, an increase in $G_{N}$ leads to a substantial real exchange rate depreciation [see Fig. 2.1(B)]. By raising the marginal product of capital in that sector, the relative price of nontraded goods must decline in order for long-run sectoral rates of return to remain equal. This has an offsetting effect insofar as sectoral resource allocation is concerned. However, the productivity enhancement in the nontraded sector facilitates an expansion of nontraded consumption, which is also encouraged by the decline in its relative price. Indeed, nontraded consumption increases substantially more than does traded consumption.

In addition, the productivity improvement in the nontraded sector boosts the accumulation of capital. Indeed, the capital stock increases even when the traded sector is capital intensive, although by less than when the sectoral capital intensities are reversed. The economy allocates the extra capital to both sectors, and the capital-labor ratios rise in the new steady state [see Figs. 1.1, 3.2].

This use of aid (higher $G_{N}$ ) leads to the largest decline in the domestic traded sector. This is because the decline in $p$ makes consumption of the nontraded good more attractive. The shift of labor from the traded to the nontraded sector is larger than for a pure transfer, contributing to the greater decline of traded production. And while the labor shift is slightly lower than in the case of higher $G_{T}$, increasing $G_{N}$ does not boost traded productivity as does $G_{T}$. On the demand side, the wealth-driven desire for more traded consumption is partially curtailed by the real depreciation, so $\tilde{C}_{T}$ rises less than in the other scenarios [see Fig. 4.1]. As usual, aid constitutes a transfer of resources from abroad that can satisfy a rise in traded consumption without the need for additional domestic traded production, which explains how the increase in traded consumption is consistent with the sharp decline in domestic traded production.

Aggregate output rises in the new steady state, but by much less than when the productive government spending is devoted to the traded sector. Traded output and the relative price of nontraded output are lower in the current scenario (higher $G_{N}$ ) than the previous one (higher $G_{T}$ ), more than compensating for the higher quantity of nontraded output in the current scenario.

The long-run rise in the capital stock more than offsets the fall in the real exchange rate, permitting a modest increase in the debt level. Until the additional capital stock is accumulated, transitional consumption is lower than in the new steady state. But despite this suppression of consumption, the country initially runs a substantial current account deficit as it increases net imports of traded goods. Thus, during the transition, debt vastly overshoots its long run level. For this reason, as well as because of the fall in the real exchange rate that reduces the value of the capital collateral, the borrowing premium initially soars. 
The transitional dynamics of the real exchange rate are long-lasting compared to the productivity improvement in the traded sector, and they also depend on the sectoral capital intensities. The average half-life of the deviation is close to 20 periods when the traded sector is capital intensive and 30 periods when the nontraded sector is capital intensive [Fig. 2.1], whereas it is only 2-3 periods when aid is directed to the traded sector. When the traded sector is capital intensive, the real exchange rate also overshoots its long-run value slightly. On the other hand, when the nontraded sector is capital intensive, the initial response is partial and the real exchange rate continues to decrease as capital stock accumulates. Finally we may note that with capital increasing substantially over time while debt increases only gradually, the country's wealth increases, so that consumption and welfare, after their initial boost due to the transfer continue to rise over time.

\section{WELFARE ANALYSIS}

With all of these contrasting responses, what is ultimately of concern is the net impact on economic welfare. Table 4 summarizes the overall effects on intertemporal welfare, as measured by the equivalent increase in consumption flow as illustrated in Fig. 4.3. Both cases of sectoral capital intensities are considered. The table also reports the corresponding percentage change in the relative price, as well as the accumulation of capital and the size of the traded sector, thereby enabling us to see the tradeoffs between welfare, the real exchange rate, economic growth, and traded activity. The first three rows summarize the responses for the three allocations we have been discussing, while the fourth row determines the optimal mix.

In all scenarios, foreign aid, being a transfer of international resources, leads to welfare gains. The country is accumulating wealth and can expand its consumption possibility frontier. Welfare improves even in the case in which the aid is used to increase spending on $G_{T}$, which generates real exchange rate appreciation. For both cases of sectoral capital intensities, allocating aid to the traded sector is inferior to either allocation to the nontraded sector or to a pure transfer. If the traded sector is more capital intensive (Case I) then a pure transfer dominates allocation to the nontraded sector, while if the sectoral capital intensities are reversed (Case II), the opposite is true. The reason for the ranking is that the closer the initial government spending is to its respective optimum the less the benefits from allocating additional aid to it.

But none of these three polar allocations is optimal. In Case I we see that the welfare of $7.53 \%$ obtained for the pure transfer can be improved further to $7.98 \%$ by setting $\lambda=0.49, \phi=0.54$. That is, $51 \%$ of the aid should be allocated to tax reduction and $49 \%$ allocated to productivity enhancement, with $54 \%$ of that being allocated to the nontraded sector and $46 \%$ to the traded sector. This will bring the economy to the socially optimal allocation and will be associated with a $2 \%$ real appreciation of the exchange rate, accompanied by a $1.34 \%$ increase in the capital stock and a $5.14 \%$ reduction in traded output. In Case II the optimum is to increase both productive expenditures substantially ( $G_{T}$ from 0.05 to 0.108 ) and ( $G_{N}$ from 0.17 to 0.334 ). This exceeds the amount of the aid received, requiring the government to increase its taxes by 0.053 units. This will result in a welfare increase of $10.74 \%$, together with an increase in capital of $19.9 \%$, a $4 \%$ deprecation of the 
real exchange rate, and a $2.4 \%$ reduction in the traded sector. This example illustrates, not only the growth-welfare tradeoff, but also how the recipient economy needs to co-ordinate its fiscal policy with its foreign aid program.

The absence of any monotonic relationship between changes in the real exchange rate and welfare implies that the real exchange rate appreciation associated with expenditure in the traded sector is an equilibrium effect, and should not be considered a 'disease' at all. Contrary to the general view of Dutch disease as an appreciation of the real exchange rate that leads to a contraction of the traded sector, we find that the traded sector actually contracts the most when the real exchange rate depreciates sharply (associated with spending on $G_{N}$ ) and contracts the least (and even expands in Case II) in the case of real appreciation (associated with spending on $G_{T}$ ). This occurs because when there is intersectoral mobility of capital and labor, the long run real exchange rate is pinned down by supply side conditions. Thus, the real appreciation or real depreciation reflect productivity gains that expand supply in the traded or nontraded sector, respectively. A fall in the relative price of nontraded goods (depreciation) shifts consumption demand toward nontraded goods, leading to a relatively larger contraction of the traded sector than in the opposite case of real appreciation.

The capital stock rises when the nontraded sector is capital intensive. This occurs because the wealth effect of the aid leads to an expansion in the nontraded sector and requires a larger capital input to sustain production. In contrast, capital mostly falls when the traded sector is capital intensive, because the movement of labor and capital to a labor intensive sector allows for shedding of excess capital. But when the government uses aid to increase $G_{N}$, the extensive productivity gains in the sector producing capital offsets the capital shedding effect and overall capital rises.

Finally, the fact that our initial baseline is one in which the amount of government spending is below the optimum levels, implies that the tied aid inflows, while adding to productive capacity are also correcting for the non-optimal allocation of resources by the government. It is therefore important to address the case where government policy is optimal before receiving the aid inflows. Will aid improve welfare if the government is already setting preaid policies at the optimal levels, or will the aid contribute to a "transfer problem", that is, by making the recipient country worse off than before the aid transfer? We find that there is no transfer problem; in all cases, aid still leads to welfare gains. ${ }^{22}$ However, with pre-aid government expenditures being at their respective optimum, we find that the pure transfer is very close to being the optimal post-aid policy and provides larger welfare gains than either form of government spending. Moreover, in all cases the gains from aid are now less than

\footnotetext{
${ }^{22}$ The issue of the allocation of aid and the transfer problem is addressed by Yano and Nugent (1999). Using a purely static model they show that if the recipient country imposes a tariff it is possible for a transfer of capital applied to the nontraded sector to be welfare deteriorating. In the absence of such a tariff they find that the transfer unambiguously improves the recipient's welfare (as we do here).
} 
what they are when the government starts from a non-optimal initial equilibrium. ${ }^{23}$ In this respect, our results run counter to the Burnside-Dollar proposition that the benefits of aid increase with the quality of government policy.

\section{EFFECT OF COST OF DEBT}

A key parameter in our analysis is $a$, which summarizes the degree of accessibility to the world financial market. Its choice impacts directly on the equilibrium value of debt, and our benchmark value $a=0.10$ yields an equilibrium debt-output ratio of around 0.60 , which is reasonably consistent with the empirical evidence. To determine the sensitivity of the system to $a$ we have checked the cases where $a=0.01$, (easy access to financial markets), $a=0.1$ (medium access, our benchmark case) and $a=10$ ( highly restricted access to world financial markets). In all cases, since $\tilde{k}_{T}$ and $\tilde{k}_{N}$ are determined by production conditions alone, varying $a$ does not affect their long-run values and thus, has no effect on the steadystate real exchange rate, $\tilde{p}$. The main effect of the higher borrowing premium is to discourage the country from holding debt. For the cost function (22d) a 10-fold increase in $a$ is associated with a 10 -fold decline in long-run debt, $\tilde{N}$. With the long-run borrowing rate fixed by the rate of time preference this means that the long-run capital stock is independent of $a$. The changes in the steady-state values of the remaining variables are actually quite small, and hence more attention will be given to illustrating the effect of the parameter $a$ on the transitional dynamics, where we focus on the real exchange rate and the cost of borrowing.

There are depicted in Figs. 5-7, which show the three polar allocations of aid. In all figures, the benchmark cost of borrowing ( $a=0.1$ ) is shown by the solid line. The main general observation is that varying $a$ leads to sharply contrasting transitional dynamics in both the real exchange rate and the borrowing rate. The less access the economy has to the international financial market the larger is the response of the real exchange rate and the initial response of the borrowing rate.

In the case of a pure transfer and $k_{T}>k_{N}$ [Fig. 5.1(A)], the real exchange rate will initially depreciate with high access and appreciate otherwise. This is because the long-run decline in the capital stock will cause an initial appreciation, while the accompanying long-run decline in debt will have the opposite effect. With high (restricted) access the latter (former) effect will dominate.

If the aid is allocated to the traded sector (Fig. 6) and the traded sector is capital intensive, the adjustment of the relative sectoral capital intensities in both sectors, the real exchange rate and the interest rate, is faster the higher the cost of borrowing, $a$. When the nontraded sector is capital intensive, the interest rate overshoots its steady state. Thus, if an aid-recipient

\footnotetext{
${ }^{23}$ These results are available on request from the authors. For example, in Case 1 the gains corresponding to optimal allocation are now $7.36 \%$ rather than $7.98 \%$ as in Table 4.
} 
country facing very large costs of external borrowing invests its funds entirely into the traded sector, it will tend to experience high economic volatility.

If the aid is allocated to the nontraded sector only (Fig. 7), with easy access to the financial markets $(a=0.01)$, after about 5 periods, the sectoral capital intensities, real exchange rate and the interest rate remain almost entirely unchanged throughout the transition. That is, with a productivity shock to the nontraded sector the opposite case happens in comparison to a shock to the traded sector, and the convergence happens quicker the lower the cost of external borrowing.

\section{Conclusions}

This paper has addressed an important issue, namely the role of real exchange rate adjustments in determining the effect of foreign aid on economic performance. The main conclusion is that concerns about Dutch disease causing untied aid to have adverse effects are essentially unfounded. As long as capital can be freely moved between sectors pure transfers have no long-run effects on the real exchange rate. While the traded sector will decline, this is because the aid, being denominated in traded output, substitutes for exports in financing imports, rather than because of Dutch disease effects. And while untied aid does lead to real exchange appreciation in the short run, these effects tends to be very temporary and to be almost negligibly small. In contrast, tied transfers do generate permanent relative price effects. Aid directed toward productivity enhancement of the traded sector will lead to an appreciation of the real exchange rate, via the Balassa-Samuelson effect, but if directed toward the nontraded sector, it will lead to real exchange rate depreciation.

Our analysis has emphasized the tradeoffs that exist between (i) real exchange movements, (ii) long-run capital accumulation, and (iii) economic welfare as measured by intertemporal utility. These are clearly relevant to policymakers in their decisions to allocate aid. Thus, while untied aid through its pure wealth enhancement raises economic welfare, and has no long-run relative price effect, it may be associated with a long-run decline in the country's capital stock if the traded sector is more capital intensive. And while aid tied to productivity enhancement in the traded sector generates an undesired appreciation of the exchange rate, and may also lead to a decline in the capital stock (pending sectoral capital intensities), the enhanced productivity is likely the dominant effect leading to a net welfare increase. But with infrastructure being produced in the nontraded sector, the greater increases in productive capital and welfare gains are likely to come from allocating the aid to productivity enhancement of the nontraded sector.

While our simulations provide some support for this last statement, the relative merits of the different allocations of aid depend upon the existing (pre-aid) structure of the economy and the government's commitment to investment in infrastructure. This suggests two final points. First, the optimal allocation is to share the aid across the various uses we have been discussing. Second, the diversity of the effects of aid across alternative uses may help explain the inclusive empirical results relating aid to growth and to real exchange rate movements. 
Table 1. The Benchmark Economy

\begin{tabular}{|ll|}
\hline Preference parameters: & $\gamma=-1.5, \theta=0.5, \rho=0.05$ \\
Production parameters: & I. $\alpha=0.35, \beta=0.25 ;$ II. $\alpha=0.25, \beta=0.35$ \\
Productivity parameters: & $A=2, B=1.7$ \\
Depreciation rate: & $\delta_{K}=0.05$ \\
World interest rate: & $r^{*}=0.03$ \\
Premium on borrowing: & $a=0.1$ \\
Weight on the premium: & $\xi=1$ \\
Government Expenditure: & $G_{T}=0.05, G_{N}=0.17$ \\
Elasticities of government expenditures: & $v_{1}=0.1, v_{2}=0.15$ \\
Transfers: & $T R=0.0$ \\
\hline
\end{tabular}

Table 2. Key Steady-State Equilibrium Ratios

A. Traded sector more capital intensive: $\alpha=0.35, \beta=0.25$

\begin{tabular}{|c|c|c|c|c|c|c|c|c|c|c|c|}
\hline$\frac{K_{T}}{L_{T}}$ & $\frac{K_{N}}{L_{N}}$ & $\frac{p K_{T}}{X}$ & $\frac{K_{N}}{Y}$ & $\frac{p K}{X+p Y}$ & $L_{T}$ & $p$ & $\frac{X}{X+p Y}$ & $\frac{G_{T}}{G}$ & $\frac{p G_{T}}{X}$ & $\frac{G_{N}}{Y}$ & $\frac{p G}{X+p Y}$ \\
\hline 7.802 & 4.830 & 3.5 & 2.5 & 2.888 & 0.355 & 1.365 & 0.388 & 0.227 & 0.063 & 0.136 & 0.108 \\
\hline
\end{tabular}

B. Nontraded sector more capital intensive: $\alpha=0.25, \beta=0.35$

\begin{tabular}{|c|c|c|c|c|c|c|c|c|c|c|c|}
\hline$\frac{K_{T}}{L_{T}}$ & $\frac{K_{N}}{L_{N}}$ & $\frac{p K_{T}}{X}$ & $\frac{K_{N}}{Y}$ & $\frac{p K}{X+p Y}$ & $L_{T}$ & $p$ & $\frac{X}{X+p Y}$ & $\frac{G_{T}}{G}$ & $\frac{p G_{T}}{X}$ & $\frac{G_{N}}{Y}$ & $\frac{p G}{X+p Y}$ \\
\hline 6.393 & 10.33 & 2.5 & 3.5 & 3.102 & 0.433 & 0.922 & 0.398 & 0.227 & 0.045 & 0.102 & 0.079 \\
\hline
\end{tabular}


Table 3. Steady-State Responses to Permanent Changes

\begin{tabular}{|c|c|c|c|c|c|c|c|c|c|c|c|c|}
\hline \multicolumn{13}{|c|}{ A. $\alpha=0.35, \beta=0.25$ (traded sector is more capital intensive) } \\
\hline & K & $N$ & $k_{T}$ & $k_{N}$ & $p$ & $L_{T}$ & $X$ & $Y$ & Z & $C_{T}$ & $C_{N}$ & C \\
\hline $\begin{array}{l}\text { Benchmark } \\
G_{T}=0.05, G_{N}=0.17 \\
T=0.22, T R=0.0\end{array}$ & 5.884 & 1.590 & 7.802 & 4.830 & 1.365 & 0.355 & 1.079 & 1.247 & 2.781 & 1.000 & 0.732 & 1.999 \\
\hline $\begin{array}{l}\text { Pure Transfer }(\lambda=0) \\
G_{T}=0.05, G_{N}=0.17 \\
T=0.110, T R=0.15\end{array}$ & 5.808 & 1.570 & 7.802 & 4.830 & 1.365 & 0.329 & 1.001 & 1.296 & 2.770 & 1.073 & 0.786 & 2.146 \\
\hline $\begin{array}{l}\text { Tied Transfer }(\lambda=1, \phi=0) \\
G_{T}=0.1486, G_{N}=0.17 \\
T=0.22, T R=0.15\end{array}$ & 5.747 & 1.732 & 7.802 & 4.830 & 1.522 & 0.309 & 1.047 & 1.336 & 3.080 & 1.110 & 0.730 & 2.221 \\
\hline $\begin{array}{l}\text { Tied Transfer }(\lambda=1, \phi=1) \\
G_{T}=0.05, G_{N}=0.2877 \\
T=0.22, T R=0.15\end{array}$ & 6.391 & 1.613 & 8.668 & 5.366 & 1.275 & 0.310 & 0.980 & 1.480 & 2.866 & 1.049 & 0.823 & 2.098 \\
\hline \multicolumn{13}{|c|}{ B. $\alpha=0.25, \beta=0.35$ (nontraded sector is more capital intensive) } \\
\hline & $K$ & $N$ & $k_{T}$ & $k_{N}$ & $p$ & $L_{T}$ & $X$ & $Y$ & $Z$ & $C_{T}$ & $C_{N}$ & $C$ \\
\hline $\begin{array}{l}\text { Benchmark } \\
G_{T}=0.05, G_{N}=0.17 \\
T=0.22, T R=0.0\end{array}$ & \begin{tabular}{|l|l} 
& 8.624
\end{tabular} & 1.574 & 6.393 & $\mid 10.33$ & 0.922 & 0.433 & 1.021 & 1.673 & 2.563 & 0.942 & 1.022 & 1.884 \\
\hline $\begin{array}{l}\text { Pure Transfer }(\lambda=0) \\
G_{T}=.05, G_{N}=0.17 \\
T=0.0573, T R=0.15\end{array}$ & 8.743 & 1.596 & 6.393 & 10.33 & 0.922 & 0.403 & 0.949 & 1.763 & 2.574 & 1.019 & 1.106 & 2.039 \\
\hline $\begin{array}{l}\text { Tied Transfer }(\lambda=1, \phi=0) \\
G_{T}=0.1922, G_{N}=0.17 \\
T=0.22, T R=0.15\end{array}$ & 8.833 & 1.845 & 6.393 & \begin{tabular}{|l|}
10.33 \\
\end{tabular} & 1.055 & 0.380 & 1.024 & 1.830 & 2.954 & 1.082 & 1.026 & 2.164 \\
\hline $\begin{array}{l}\text { Tied Transfer }(\lambda=1, \phi=1) \\
G_{T}=0.05, G_{N}=0.3548 \\
T=0.22, T R=0.15\end{array}$ & 10.46 & 1.681 & 7.576 & 12.24 & 0.811 & 0.381 & 0.937 & 2.164 & 2.693 & 1.003 & 1.236 & 2.005 \\
\hline
\end{tabular}


Table 4. Welfare Analysis

Long-run changes and welfare gains for transfers of 0.15:

Starting from initial allocation: $G_{T}=0.05 ; G_{N}=0.17 ; T=0.22 ; T R=0.0$

I. Traded sector more capital intensive $\alpha=0.35, \beta=0.25$ :

\begin{tabular}{|l|c|c|c|c|}
\hline & $\% \Delta \tilde{p}$ & $\% \Delta \tilde{K}$ & $\% \Delta \tilde{X}$ & $\begin{array}{c}\text { \% Long-run } \\
\text { Welfare Gain }\end{array}$ \\
\hline $\begin{array}{l}\text { pure transfer }(\lambda=0): \\
G_{T}=0.05 ; G_{N}=0.17 ; T=0.11\end{array}$ & 0 & -1.29 & -7.24 & 7.53 \\
\hline $\begin{array}{l}\text { spent on } G_{T} \text { only }(\lambda=1 ; \phi=0): \\
G_{T}=0.149 ; G_{N}=0.17 ; T=0.22\end{array}$ & 11.5 & -2.33 & -2.97 & 6.15 \\
\hline $\begin{array}{l}\text { spent on } G_{N} \text { only }(\lambda=1 ; \phi=1): \\
G_{T}=0.05 ; G_{N}=0.288 ; T=0.22\end{array}$ & -6.6 & 8.62 & -9.23 & 6.85 \\
\hline $\begin{array}{l}\text { Opt. alloc. }(\lambda=0.49 ; \phi=0.54): \\
G_{T}=0.074 ; G_{N}=0.199 ; T=0.165\end{array}$ & 2.0 & 1.34 & -5.14 & 7.98 \\
\hline
\end{tabular}

II. Nontraded sector more capital intensive $\alpha=0.25, \beta=0.35$ :

\begin{tabular}{|l|c|c|c|c|}
\hline & $\% \Delta \tilde{p}$ & $\% \Delta \tilde{K}$ & $\% \Delta \tilde{X}$ & $\begin{array}{c}\text { \% Long-run } \\
\text { Welfare Gain }\end{array}$ \\
\hline $\begin{array}{l}\text { pure transfer }(\lambda=0): \\
G_{T}=0.05 ; G_{N}=0.17 ; T=0.057\end{array}$ & 0 & 1.38 & -7.03 & 7.94 \\
\hline $\begin{array}{l}\text { spent on } G_{T} \text { only }(\lambda=1 ; \phi=0): \\
G_{T}=0.192 ; G_{N}=0.17 ; T=0.22\end{array}$ & 14.4 & 2.42 & 0.37 & 7.55 \\
\hline $\begin{array}{l}\text { spent on } G_{N} \text { only }(\lambda=1 ; \phi=1): \\
G_{T}=0.05 ; G_{N}=0.355 ; T=0.22\end{array}$ & -12.0 & 21.29 & -8.17 & 9.51 \\
\hline $\begin{array}{l}\text { Opt. alloc. }(\lambda=1.31 ; \phi=0.74): \\
G_{T}=0.108 ; G_{N}=0.334 ; T=0.273\end{array}$ & -4.0 & 19.91 & -2.42 & 10.74 \\
\hline
\end{tabular}


Figure 1. Capital and Debt

(A) Traded sector more capital intensive:

( $\alpha=0.35, \beta=0.25)$
(B) Nontraded sector more capital intensive:

( $\alpha=0.25, \beta=0.35$ )

\subsection{Time Path for Capital $(K)$}
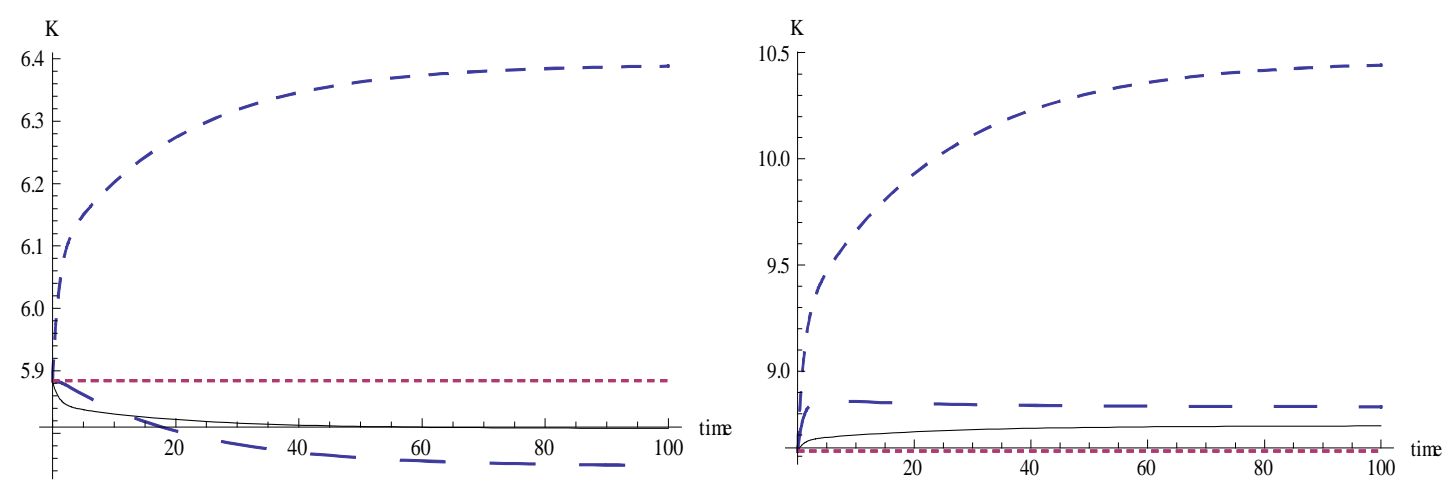

\subsection{Time Path for Debt $(N)$}
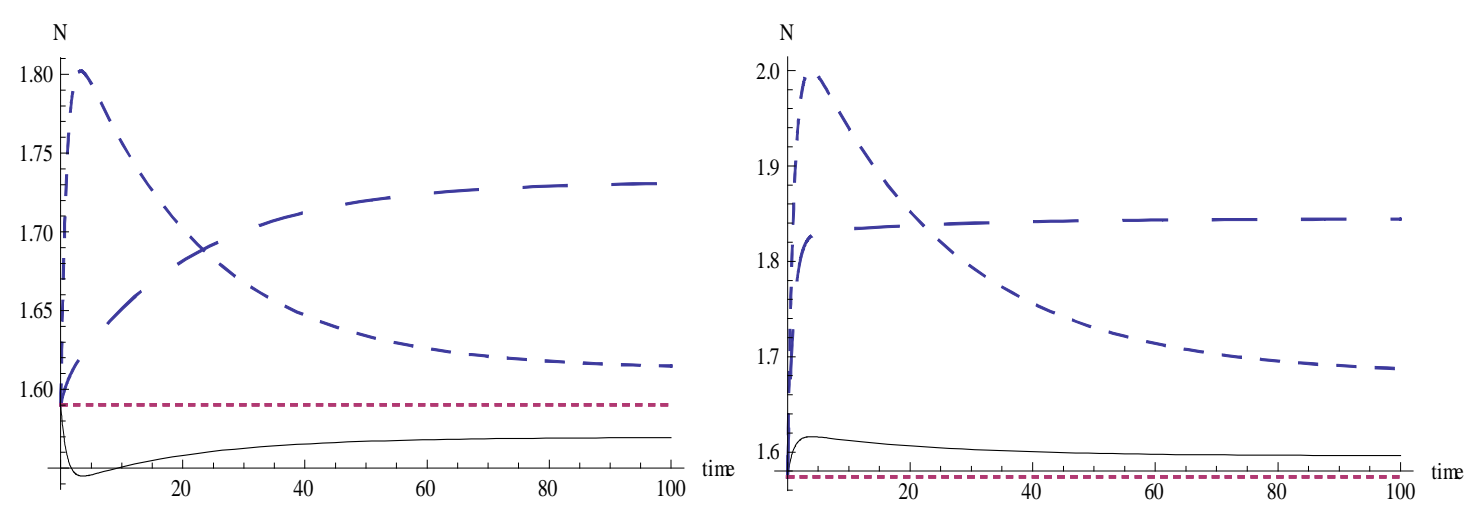

pure transfer

$G^{T}$

$G^{N}$ -Initial SS 
Figure 2. Financial Variables

(A) Traded sector more capital intensive:

( $\alpha=0.35, \beta=0.25$ )
(B) Nontraded sector more capital intensive:

( $\alpha=0.25, \beta=0.35$ )

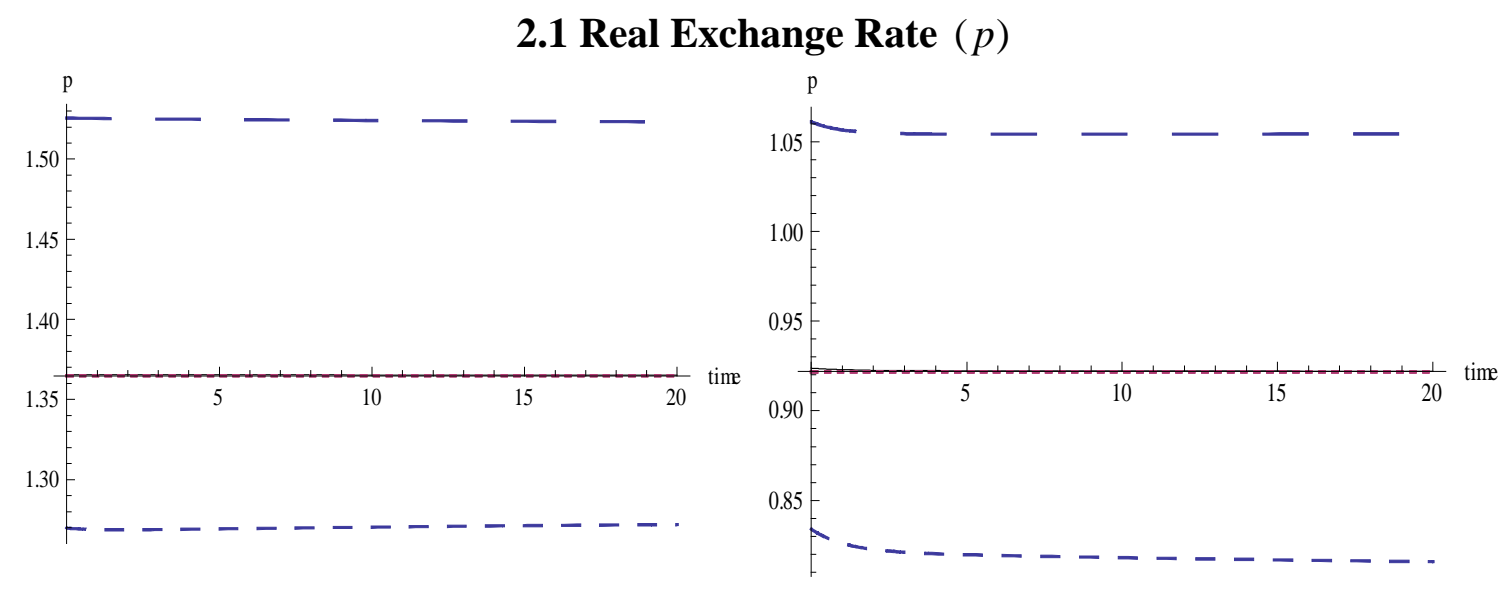

2.2 Interest Rate ( $r$ )
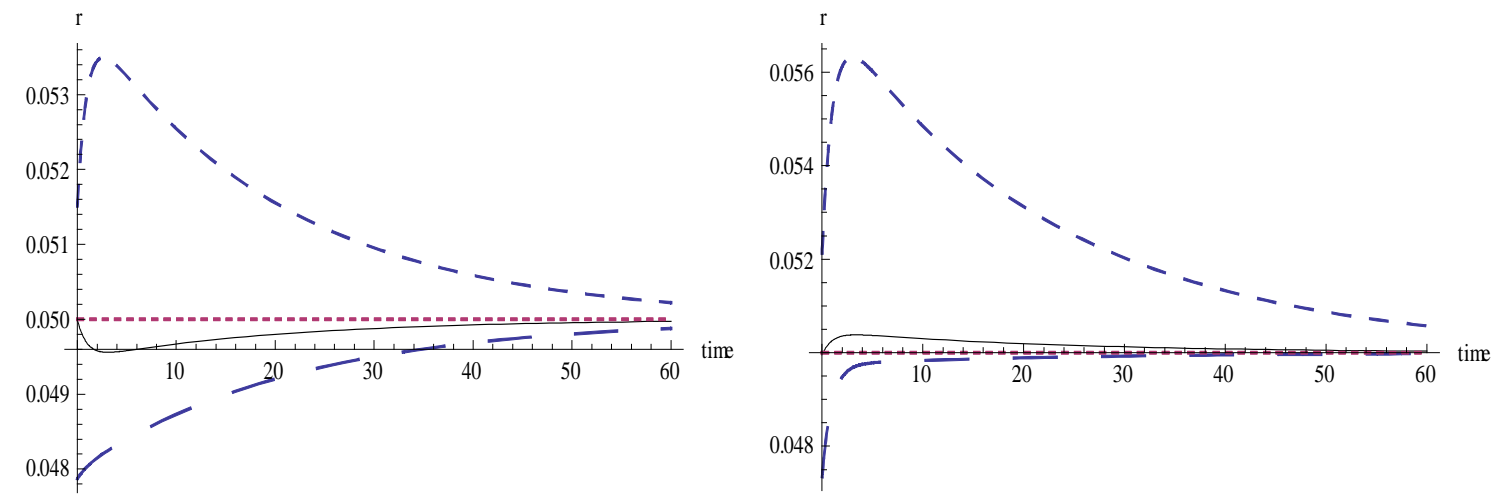

pure transfer

$G^{T}$

$G^{N}$ -Initial SS 
Figure 3. Sectoral Activity and Output

(A) Traded sector more capital intensive:

( $\alpha=0.35, \beta=0.25$ )
(B) Nontraded sector more capital intensive:

( $\alpha=0.25, \beta=0.35$ )

\subsection{Labor Share in Traded Sector $\left(L^{T}\right)$}
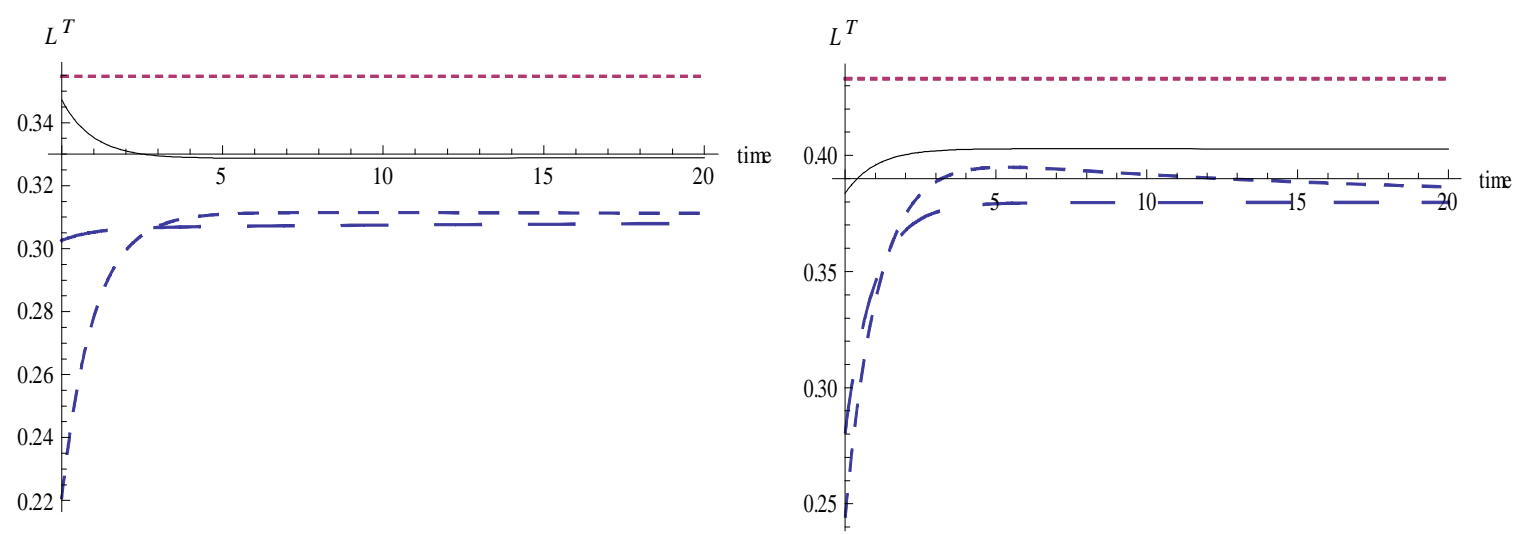

\subsection{Capital Intensity in Traded Sector $\left(k^{T}\right)$}
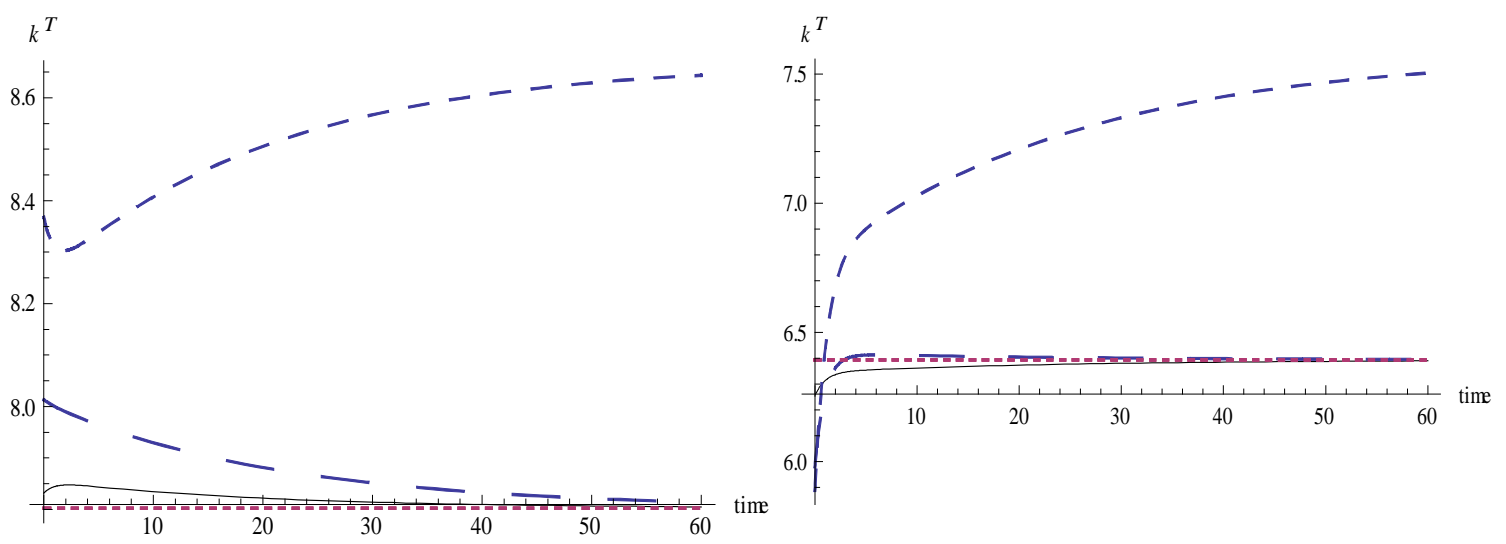

pure transfer

$G^{T}$ $G^{N}$ -Initial SS 
(A) Traded sector more capital intensive:

( $\alpha=0.35, \beta=0.25)$
(B) Nontraded sector more capital intensive:

( $\alpha=0.25, \beta=0.35$ )

\subsection{Traded Output $(X)$}
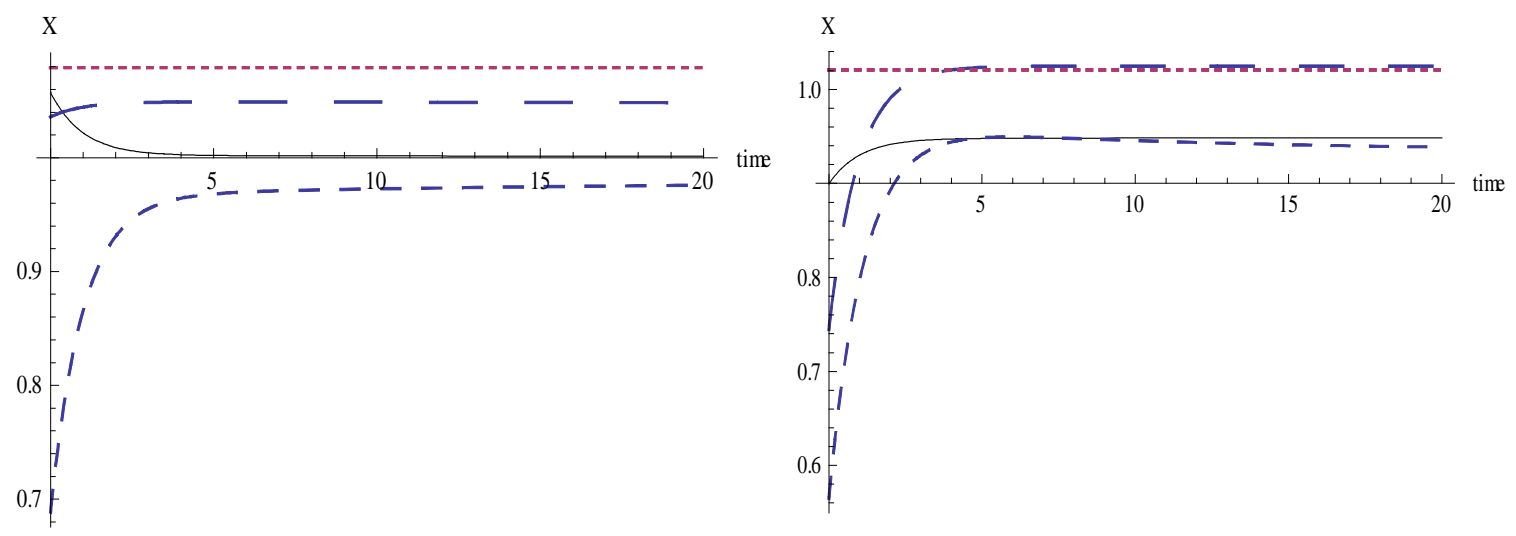

\subsection{Nontraded Output $(Y)$}
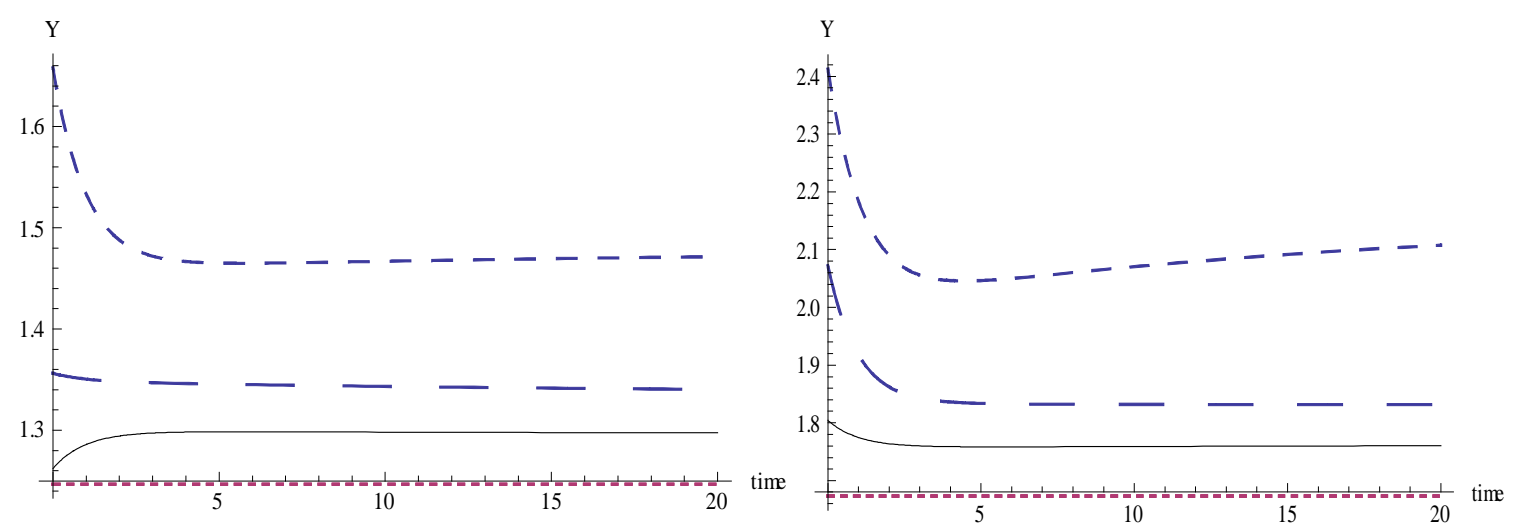

pure transfer

$G^{T}$ $G^{N}$ -Initial SS 
Figure 4. Consumption and Welfare

(A) Traded sector more capital intensive:

( $\alpha=0.35, \beta=0.25$ )
(B) Nontraded sector more capital intensive:

( $\alpha=0.25, \beta=0.35$ )
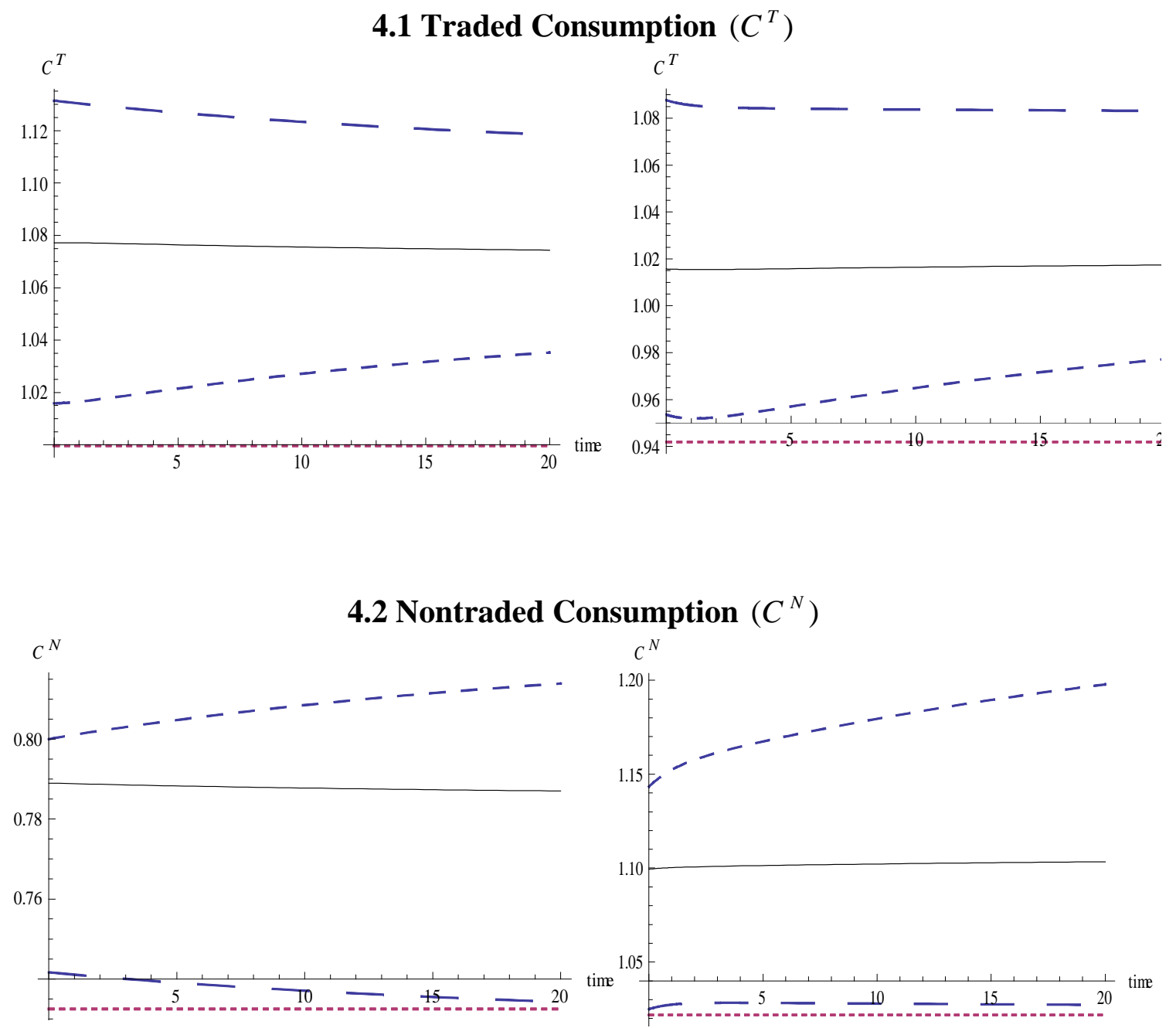

pure transfer

$G^{T}$

$G^{N}$ -Initial SS 
(A) Traded sector more capital intensive:

$(\alpha=0.35, \beta=0.25)$
(B) Nontraded sector more capital intensive:

( $\alpha=0.25, \beta=0.35$ )

\subsection{Welfare $(W)$}

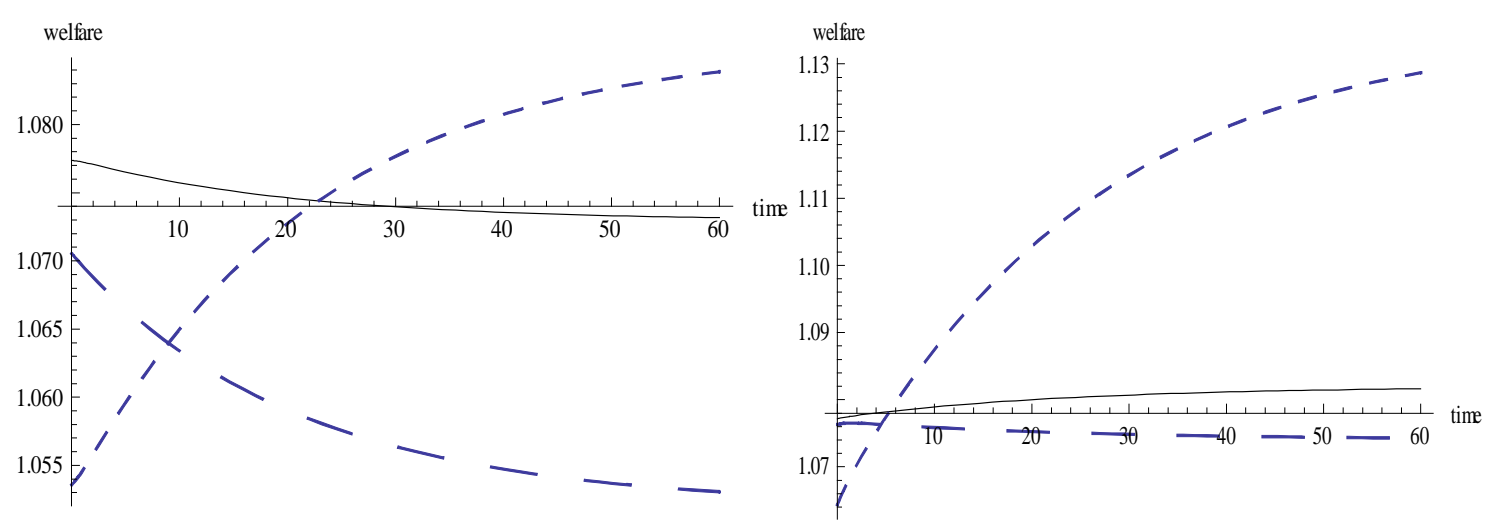

$$
\text { pure transfer } \quad \_\_\_-G^{T} \quad--------G^{N} \text {-------------Initial SS }
$$


Figure 5. Sensitivity to Borrrowing Premium: Untied Transfer

(A) Traded sector more capital intensive: $\alpha=0.35, \beta=0.25$
(B) Nontraded sector more capital intensive: $\alpha=0.25, \beta=0.35$
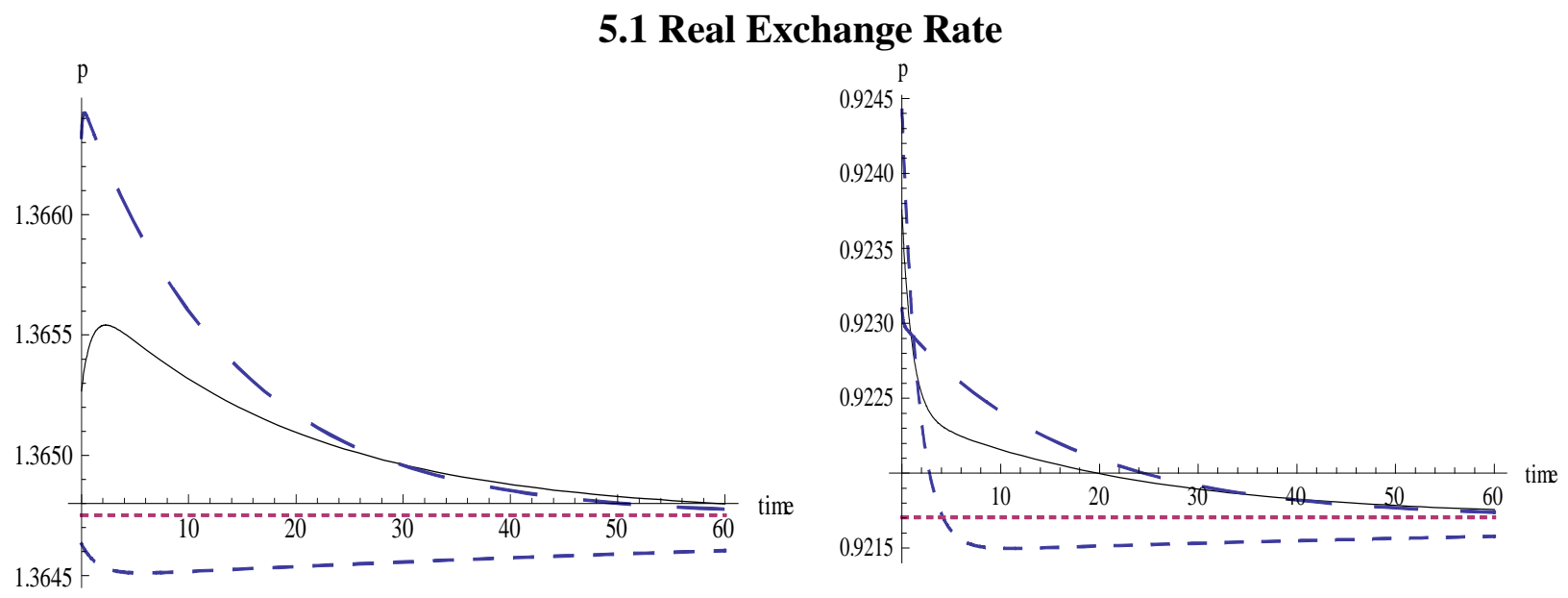

\subsection{Borrowing Rate}

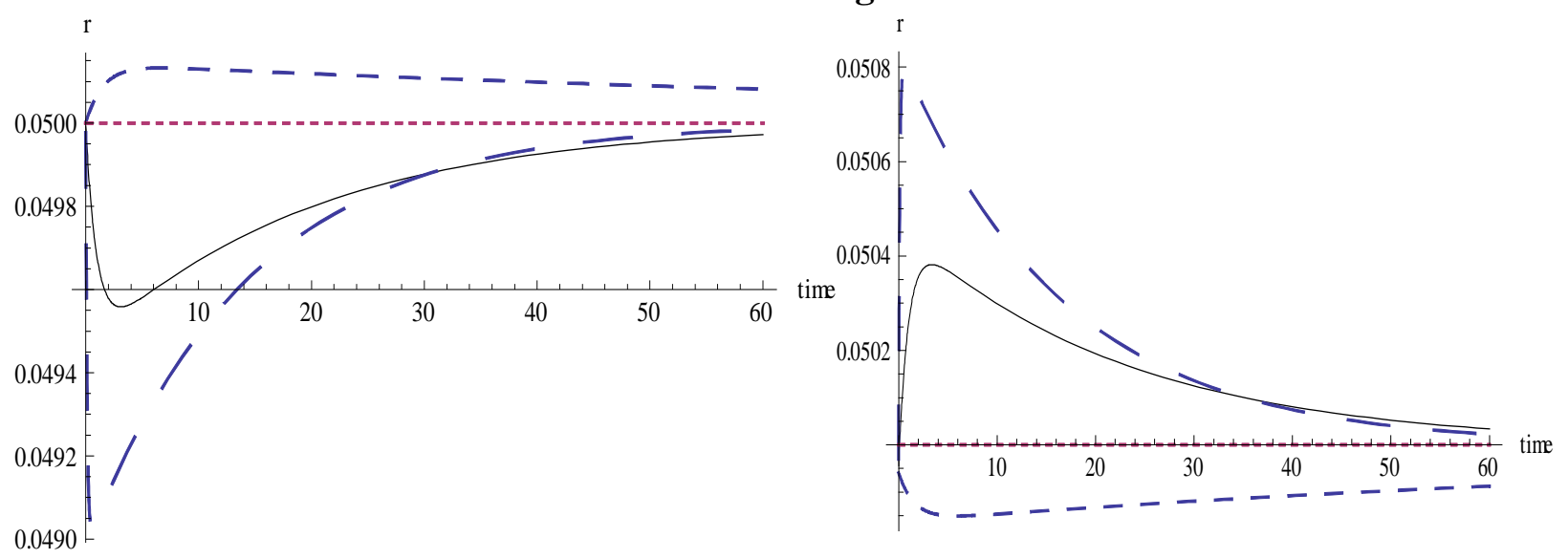


Figure 6: Sensitivity to Borrowing Premium: Productive Transfer to Traded Sector

(A) Traded sector more capital intensive: $\alpha=0.35, \beta=0.25$
(B) Nontraded sector more capital intensive: $\alpha=0.25, \beta=0.35$

\subsection{Real Exchange Rate}
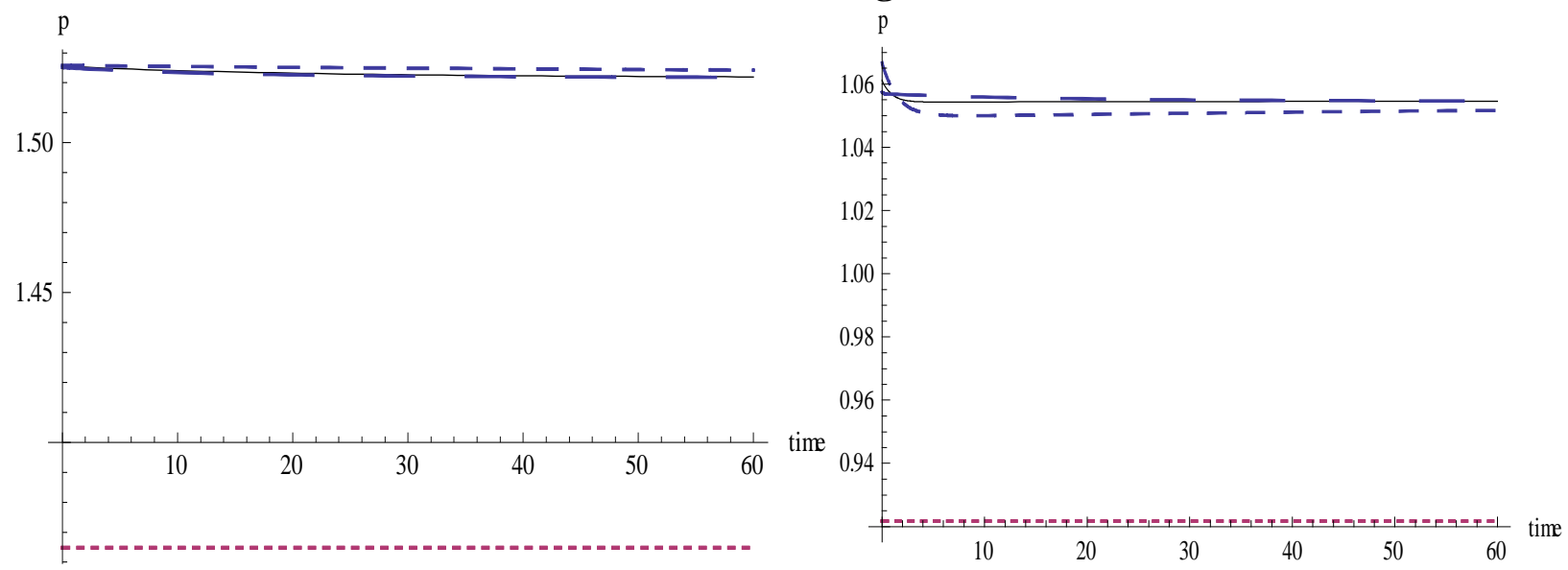

\subsection{Borrowing Rate}

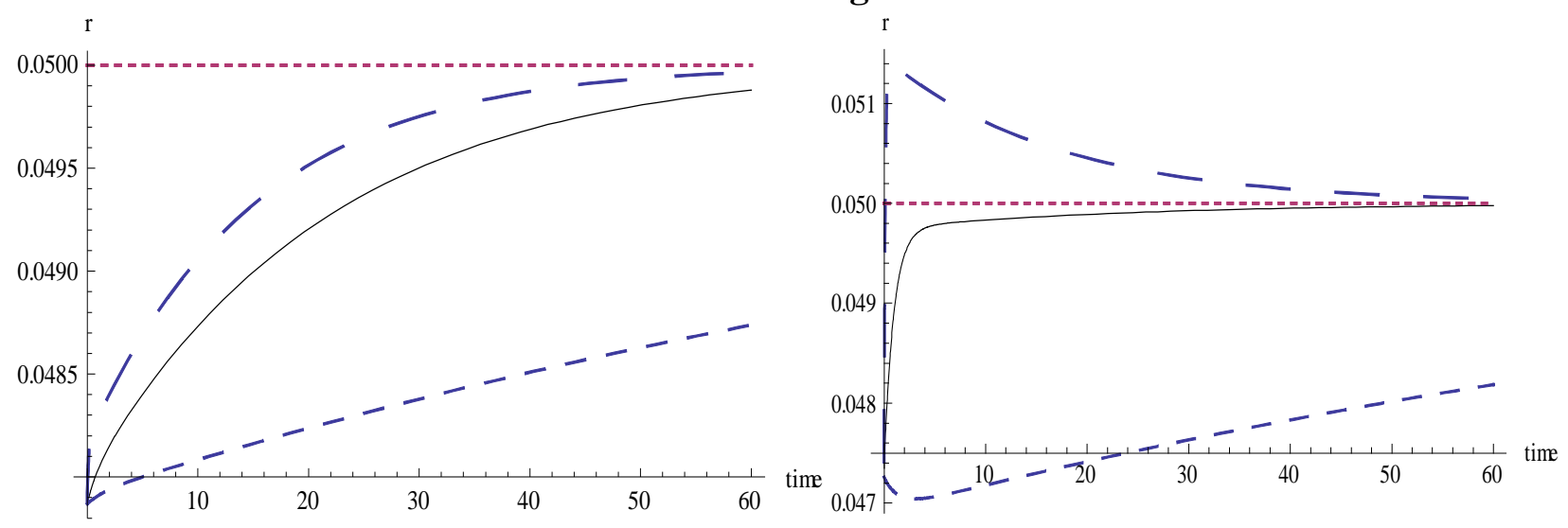


Figure 7: Sensitivity to Borrowing Premium: Productive Transfer to Nontraded Sector

(A) Traded sector more capital intensive: $\alpha=0.35, \beta=0.25$
(B) Nontraded sector more capital intensive: $\alpha=0.25, \beta=0.35$

\subsection{Real Exchange Rate}
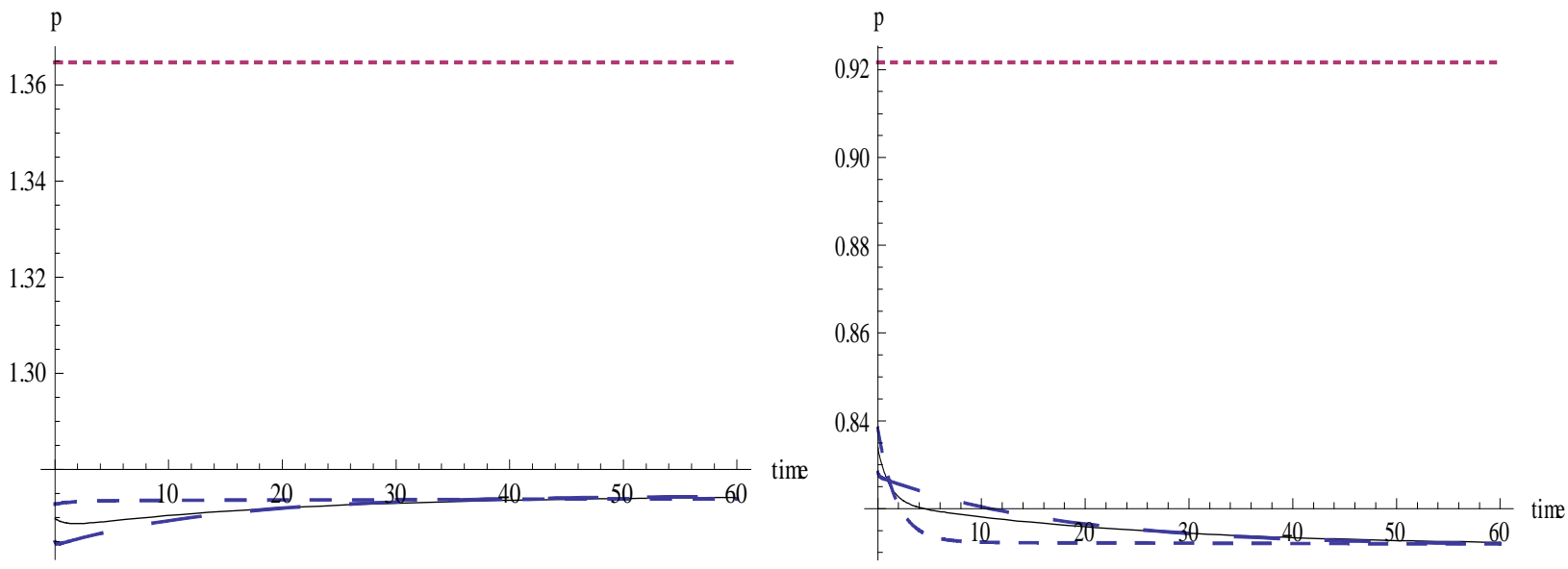

\subsection{Borrowing Rate}
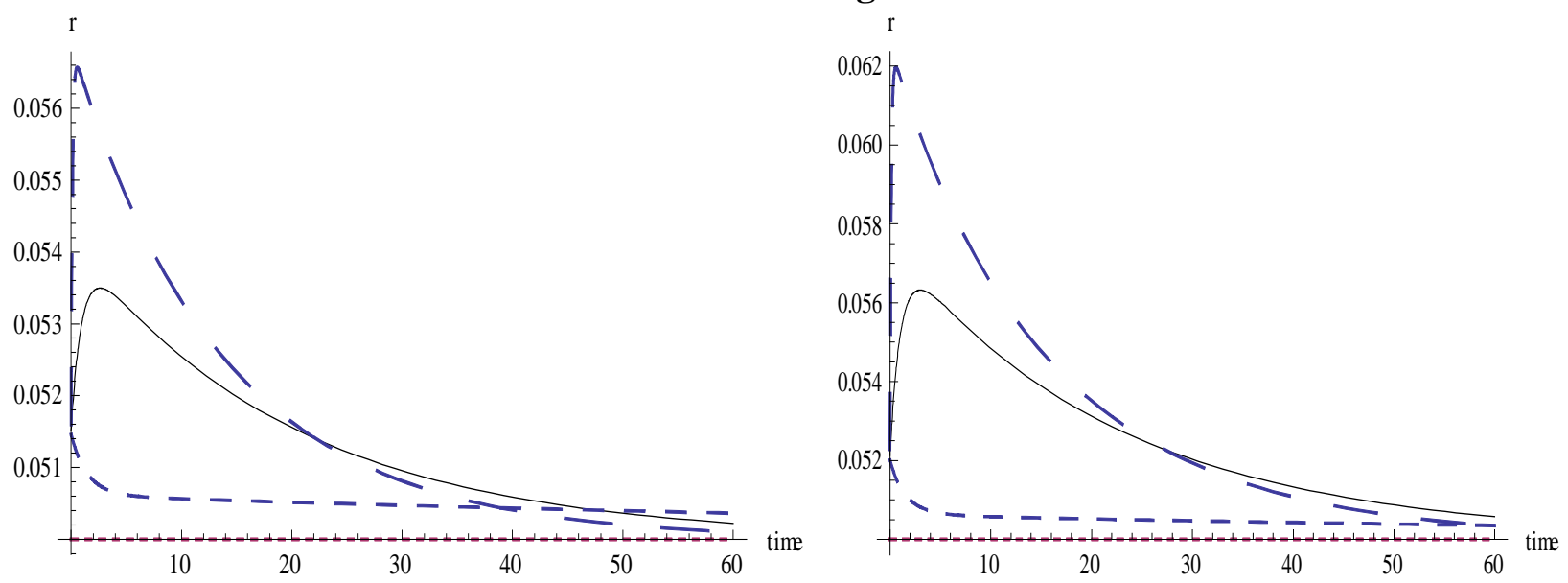

$\mathrm{a}=0.01$ (high access) $\mathrm{a}=0.1$ ( medium access) $\mathrm{a}=10$ (low access) 


\section{Appendix}

A.1

Properties of (15a) - (15c)

$$
\begin{gathered}
\frac{\partial k_{T}}{\partial p}=\frac{h}{f_{k k}\left(k_{N}-k_{T}\right)} ; \frac{\partial k_{T}}{\partial G_{T}}=-\frac{\left[f_{G}-\left(k_{T}-k_{N}\right) f_{K G}\right]}{f_{k k}\left(k_{N}-k_{T}\right)} ; \frac{\partial k_{T}}{\partial G_{N}}=\frac{p h_{G}}{f_{k k}\left(k_{N}-k_{T}\right)} \\
\frac{\partial k_{N}}{\partial p}=\frac{f}{p^{2} h_{k k}\left(k_{N}-k_{T}\right)} ; \frac{\partial k_{N}}{\partial G_{T}}=-\frac{f_{G}}{p h_{k k}\left(k_{N}-k_{T}\right)} ; \frac{\partial k_{N}}{\partial G_{N}}=\frac{h_{G}-\left(k_{N}-k_{T}\right) h_{K G}}{h_{k k}\left(k_{N}-k_{T}\right)} \\
\frac{\partial L_{T}}{\partial K}=\frac{1}{k_{T}-k_{N}} ; \frac{\partial L_{T}}{\partial p}=\left[\frac{\left(1-L_{T}\right) f}{p^{2} h_{k k}}+\frac{L_{T} h}{f_{k k}}\right] \frac{1}{\left(k_{T}-k_{N}\right)^{2}}<0 ; \\
\frac{\partial L_{T}}{\partial G_{i}}=\frac{1}{k_{N}-k_{T}}\left[L_{T} \frac{\partial k_{T}}{\partial G_{i}}+\left(1-L_{T}\right) \frac{\partial k_{N}}{\partial G_{i}}\right] \quad i=T, N
\end{gathered}
$$

A.2 Properties of (16a) - (16b)

$$
\begin{aligned}
& \frac{\partial X}{\partial K}=\frac{f}{k_{T}-k_{N}} ; \quad \frac{\partial X}{\partial p}=\left[\frac{\left(1-L_{T}\right) f^{2}}{p^{2} h_{k k}}+\frac{L_{T} h^{2} p}{f_{k k}}\right] \frac{1}{\left(k_{T}-k_{N}\right)^{2}}<0 ; \\
& \frac{\partial X}{\partial G_{T}}=\frac{\partial L_{T}}{\partial G_{T}} f+L_{T} f_{k} \frac{\partial k_{T}}{\partial G_{T}}+L_{T} f_{G} ; \quad \frac{\partial X}{\partial G_{N}}=\frac{\partial L_{T}}{\partial G_{N}} f+L_{T} f_{k} \frac{\partial k_{T}}{\partial G_{N}} \\
& \frac{\partial Y}{\partial K}=\frac{h}{k_{N}-k_{T}} ; \quad \frac{\partial Y}{\partial p}=-\left[\frac{L_{T} p h^{2}}{f^{\prime \prime}}+\frac{\left(1-L_{T}\right) f^{2}}{p^{2} h^{\prime \prime}}\right] \frac{1}{p\left(k_{T}-k_{N}\right)^{2}}>0 ; \\
& \frac{\partial Y}{\partial G_{T}}=-\frac{\partial L_{T}}{\partial G_{T}} h+L_{N} h_{k} \frac{\partial k_{N}}{\partial G_{T}} ; \quad \frac{\partial Y}{\partial G_{N}}=-\frac{\partial L_{T}}{\partial G_{N}} h+L_{N} h_{k} \frac{\partial k_{N}}{\partial G_{N}}+L_{N} h_{G}
\end{aligned}
$$

\section{A.3 Long-run Effects of Pure Transfer}

$$
\begin{aligned}
& \frac{\partial \tilde{C}_{T}}{\partial T R}=-\frac{U_{B} \tilde{K}}{\Delta}\left[h-\delta_{K}\left(k_{N}-k_{T}\right)\right]>0 \\
& \frac{\partial \tilde{C}_{N}}{\partial T R}=-\frac{U_{A} \tilde{K}}{\Delta}\left[h-\delta_{K}\left(k_{N}-k_{T}\right)\right]>0 \\
& \frac{\partial \tilde{L}_{T}}{\partial T R}=\frac{U_{A} \tilde{K}}{\Delta}<0
\end{aligned}
$$




$$
\begin{aligned}
& \frac{\partial \tilde{X}}{\partial T R}=\frac{U_{A} \tilde{K} f}{\Delta}<0 \\
& \frac{\partial \tilde{Y}}{\partial T R}=-\frac{U_{A} \tilde{K} h}{\Delta}>0 \\
& \frac{\partial \tilde{Z}}{\partial T R}=\frac{U_{A} \tilde{K}(f-\tilde{p} h)}{\Delta} \\
& \frac{\partial \tilde{K}}{\partial T R}=\frac{U_{A} \tilde{K}}{\Delta}\left(\tilde{k}_{T}-\tilde{k}_{N}\right) \\
& \frac{\partial \tilde{N}}{\partial T R}=\frac{U_{A} \tilde{N}}{\Delta}\left(\tilde{k}_{T}-\tilde{k}_{N}\right)
\end{aligned}
$$

where $U_{A} \equiv \tilde{p} U_{T T}-U_{N T}<0, U_{B} \equiv U_{N N}-\tilde{p} U_{N T}<0$, and

$$
\Delta \equiv-\left(f U_{A}+h U_{B}\right) \tilde{K}+\left(\tilde{k}_{T}-\tilde{k}_{N}\right)\left[U_{A} \rho \tilde{N}-U_{B} \delta_{K} \tilde{K}\right]>0
$$




\section{References}

Adam, C.S. and D.L. Bevan, 2006, “Aid and the supply side: Public investment, export performance, and Dutch disease in low-income countries," World Bank Economic Review, Vol. 20, pp. 261-90.

Arellano, C., A. Buliř, T. Lane, and L. Lipschitz, 2008,, “The dynamics implications of foreign and its variability,” Journal of Development Economics (forthcoming).

Balassa, B., 1964, “The purchasing-power parity doctrine: A reappraisal,” Journal of Political Economy, Vol. 72, pp. 584-596.

Bardhan, P.K., 1967, “Optimal foreign borrowing,” in K. Shell (ed.), Essays on the Theory of Optimal Economic Growth (Cambridge, Massachusetts: MIT Press.)

Barro, R.J., 1990, “Government spending in a simple model of endogenous growth,” Journal of Political Economy, Vol. 98, pp. S103-S125.

Brock, P.L., 1988, "Investment, the current account, and the relative price of nontraded goods in a small open economy,” Journal of International Economics, Vol. 24, pp. 235-53

Brock, P.L. and S J. Turnovsky, 1994, "The dependent economy model with traded and nontraded capital goods,” Review of International Economics, Vol. 2, pp. 306-25.

Burnside, C. and D. Dollar, 2000, “Aid, policies, and growth,” American Economic Review, Vol. 90, pp. 847-68.

Chatterjee, S., Sakoulis, G., and S.J. Turnovsky, 2003, “Unilateral capital transfers, public investment, and economic growth,” European Economic Review, Vol. 47, pp. 10771103.

Chatterjee, S. and S.J. Turnovsky, 2007, "Foreign aid and economic growth: The role of flexible labor supply,” Journal of Development Economics, Vol. 87, 2007, pp. 50733.

Collier, P. and D. Dollar, 2002, “Aid allocation and policy reduction,” European Economic Review, Vol. 46, pp. 1475-1500.

Corden, W.M., 1984, "Booming sector and Dutch disease economics: Survey and consolidation,” Oxford Economic Papers, Vol. 36, pp. 359-80.

Corden, W.M. and P.J. Neary, 1982, “Booming sector and de-industrialization in a small open economy,” Economic Journal, Vol. 92, pp. 825-48.

Dalgaard, C-J., 2008, “Donor policy rules and aid effectiveness,” Journal of Economic Dynamics and Control, Vol. 32, pp. 1895-1920. 
Dalgaard, C-J., H. Hansen, and F. Tarp, 2004, “On the empirics of foreign aid and growth,” Economic Journal, Vol. 114, pp. F217-F243.

Devarajan, S., D.S. Go, J. Page, S. Robinson, and K. Thierfelder, 2008, “Aid, growth, and real exchange rate dynamics,” World Bank Policy Research Paper 4480.

Easterly, W., 2001, The Elusive Quest for Growth: Economists' Adventures and Misadventures in the Tropics (Cambridge, Massachusetts: MIT Press)

Easterly, W., 2003, “Can foreign aid buy growth?” Journal of Economic Perspectives, Vol. 17, pp. 23-48.

Easterly, W., R. Levine, and D. Roodman, 2004, “Aid, policies, and growth: Comment,” American Economic Review, Vol. 94, pp. 774-80.

Hansen, H., and F. Tarp, 2000, “Aid effectiveness disputed,” Journal of International Development, Vol. 12, pp. 375-98.

Hansen, H., and F. Tarp, 2001, “Aid and growth regressions,” Journal of Development Economics, Vol. 64, pp. 547-70.

Isard, P., L. Lipschitz, A. Mourmouras, and B. Yontcheva (eds.), 2006, The Macroeconomic Management of Foreign Aid, Opportunities and Pitfalls (Washington, D.C.: International Monetary Fund)

Kang, J.S., A. Prati, and A. Rebucci, 2007, “Aid, exports, and growth: A time series perspective on the Dutch disease hypothesis,” International Monetary Fund.

Kiyotaki, N. and J. Moore, 1997, “Credit cycles,” Journal of Political Economy, Vol. 105, pp. 211-48.

Morshed, M. and S.J. Turnovsky, 2004, "Intersectoral adjustment costs and real exchange rate dynamics in a two-sector dependent economy model," Journal of International Economics, Vol. 62, pp. 147-77.

Nkusu, M., 2004, “Aid and the Dutch disease for low-income countries: Informed diagnoses for prudent prognoses,” IMF Working Paper 04/49.

Rajan, R. and A. Subramanian, 2005, "Aid and growth: What does the cross-country evidence really show?” NBER Working Paper 11,513.

Sachs, J., 1984, “Theoretical issues in international borrowing,” Princeton Studies in International Finance, No. 54. 
Samuelson, P.A., 1964, “Theoretical notes on trade problems," Review of Economics and Statistics, Vol. 46, pp. 145-54.

Turnovsky, S.J., 1997, International Macroeconomic Dynamics (Cambridge, Massachusetts: MIT Press.)

Turnovsky, S.J. and P. Sen, 1995, “Investment in a two-sector dependent economy,” Journal of the Japanese and International Economies, Vol. 9, pp. 29-55,

Van Wincoop, E., 1993, "Structural adjustment and the construction sector," European Economic Review, Vol. 37, pp. 177-201.

World Bank, 1994, World Development Report 1994: Infrastructure for Development. (New York: Oxford University Press)

World Bank, 2004, World Development Indicators, CD-ROM, Washington, D.C.

Yano, M. and J. Nugent, 1999, “Aid, nontraded goods, and the transfer paradox in small countries,” American Economic Review, Vol. 89, pp. 431-49 